\title{
The interrelationships of metazoan parasites: a review of phylum- and higher-level hypotheses from recent morphological and molecular phylogenetic analyses
}

\author{
Jan Zrzavý \\ Department of Zoology, Faculty of Biological Sciences, University of South Bohemia, and Institute of Entomology, Academy of \\ Sciences of the Czech Republic, Branišovská 31, 37005 České Budějovice, Czech Republic
}

Key words: phylogeny, parasitism, Myxozoa, Mesozoa, Neodermata, Myzostomida, Seisonida, Acanthocephala, Pentastomida, Nematomorpha, Nematoda

\begin{abstract}
Phylogeny of seven groups of metazoan parasitic groups is reviewed, based on both morphological and molecular data. The Myxozoa (=Malacosporea + Myxosporea) are most probably related to the egg-parasitic cnidarian Polypodium (Hydrozoa?: Polypodiozoa); the other phylogenetic hypotheses are discussed and the possible non-monophyly of the Cnidaria (with the Polypodiozoa-Myxozoa clade closest to the Triploblastica) is suggested. The Mesozoa is a monophyletic group, possibly closely related to the (monophyletic) Acoelomorpha; whether the Acoelomorpha and Mesozoa represent the basalmost triploblast clade(s) or a derived platyhelminth subclade may depend on rooting the tree of the Triploblastica. Position of the monophyletic Neodermata (=Trematoda + Cercomeromorpha) within the rhabditophoran flatworms is discussed, with two major alternative hypotheses about the neodermatan sister-group relationships (viz., the "neoophoran" and "revertospermatan"). The Myzostomida are not annelids but belong among the Platyzoa, possibly to the clade of animals with anterior sperm flagella (=Prosomastigozoa). The Acanthocephala represent derived syndermates ("rotifers"), possibly related to Seison (the name Pararotatoria comb. n. is proposed for Seisonida + Acanthocephala). The crustacean origin of the Pentastomida based on spermatological and molecular evidence (Pentastomida + Branchiura $=$ Ichthyostraca) is confronted with palaeontological views favouring the pre-arthropod derivation of the pentastomids. Phylogenetic position of the nematodes within the Ecdysozoa and evolution of nematode parasitism are discussed, and the lack of relevant information about the enigmatic ectoproctan parasite Buddenbrockia is emphasised.
\end{abstract}

At present, the metazoan relationships are becoming clearer as phylogenetic techniques are applied to morphological and molecular characters, the molecular data grow exponentially, and the "morphological" (i.e., non-sequence) information is refined by using ultrastructural and biochemical methods. In the present paper, recent contributions concerning the phylogenetic position of major parasitic animal groups are discussed. Seven taxa were selected: two "pseudo-protist" groups that evidently belong to the Metazoa and represent the most simplified multicellular animals (Myxozoa, Mesozoa), two traditional metazoan phyla that are now regarded as modified parasitic representatives of more comprehensive groups (Acanthocephala, Pentastomida), one parasitic "annelid" subgroup recently elevated to a phyletic level, unrelated to the Annelida (Myzostomida), and two major parasitic groups whose sister-group relationships and evolution of host-parasite relationships are recently becoming elucidated (Neodermata, Nematoida).

This paper is about trees. It should be emphasised here that a tree (cladogram, maximum likelihood tree, distance tree) is not (or should not be) a graphical presentation of author's personal opinion about the course of evolution. The tree represents a series of hypotheses about the character homology (whether morphological or molecular, a priori or a posteriori). Each branch of a tree is based on the underlying homology hypothesis - two taxa are related (more than any of them to any third taxon) because they share a synapomorphic (i.e., derived and homologous) character state. If the homology hypothesis is wrong, then the value of the tree itself is compromised. In this paper, the alternative trees are discussed, rather than the character datasets and tree-building methods: readers should consult the original papers. Only discussions of few well-supported (Neodermata, Syndermata) or - on the other hand-quite unorthodox groupings (Acoelomorpha + Mesozoa, Prosomastigozoa) will include short character analyses.

Most molecular studies concerning phylogeny of the Metazoa (since the seminal work by Field et al. 1988) provide results different from the conventional trees based on morphological data. Sometimes we are dealing with the conflict between gene trees and species trees, the underlying reasons including gene duplication, horizontal gene transfer, and lineage sorting problems. Moreover, even if there are no gene/species conflicts, four major methodological reasons for morphological vs. molecular conflicts are as follows: (a) use of single- 
character phylogenetic hypotheses in morphology (e.g., body cavities, cleavage patterns, type of epithelial ciliature, larval types, life cycles), (b) use of different methodologies (Hennigian cladistics as well as pure method-free story-telling in morphology versus distance and maximum-likelihood methods in molecular biology), (c) (intuitive) deducing groundplan character states of the higher group before the analysis in morphology versus coding a number of real exemplar species belonging to the group as terminals in the analysis in molecular biology (see Yeates 1995), and (d) depauperate taxonomical sampling in most molecular studies.

The "total evidence" approach that aims at finding the best-fitting phylogenetic hypothesis by combining different sets of characters into a single data matrix (see Eernisse and Kluge 1993, Nixon and Carpenter 1996) is increasingly applied to phylogenetic reconstruction of various animal higher taxa like vertebrates (Eernisse and Kluge 1993), echinoderms (Littlewood et al. 1997, Janies and Mooi 1998), flatworms (Littlewood et al. 1999a, b, 2000), and arthropods (Wheeler et al. 1993, Wheeler 1997, Whiting et al. 1997, Zrzavý et al. 1997, Edgecombe et al. 2000). The total-evidence attempts to resolve "phylum"-rank metazoan (Zrzavý et al. 1998) and triploblast (Giribet et al. 2000, Zrzavý et al. 2001) relationships are based on the extensive datasets of morphological, ultrastructural, biochemical, developmental, and ecological characters, and on numerous $18 \mathrm{~S}$ (=small subunit) ribosomal DNA sequences so that both "single character" and "few taxa" problems would be eliminated through robust sampling of both taxa and characters. The combined morphological-molecular trees show that molecular data do not overwhelm morphological data (nor vice versa) if the two sets are combined.

All recent morphological, molecular, and combined trees accord that Metazoa and Triploblastica (=Bilateria) are monophyletic groups. The positions of Porifera, Ctenophora, Placozoa, and Cnidaria within the non-triploblast Metazoa are highly unstable, and even the monophyly of Porifera and Cnidaria are disputable (see Zrzavý et al. 1998 and below). The relationships of triploblast taxa seem to be uncertain. The closer inspection reveals that major difference among most published hypotheses depends on two different kinds of tree rooting: either the most basal root is situated between Deuterostomia and Protostomia, or within the (paraphyletic) "Platyhelminthes" (Fig. 1). Probably there are four or five major triploblast groups (Giribet et al. 2000, Zrzavý et al. 2001): (a) Deuterostomia $(=$ Neorenalia $=$ Deuterostomozoa; incl. Chordata, Hemichordata, Echinodermata), (b) Ecdysozoa (incl. Scalidophora, Nematomorpha, Nematoda, Onychophora, Tardigrada, Arthropoda), (c) Lophotrochozoa (s. str.; = Lophozoa = Trochozoa s. lat.; incl. Brachiopoda, Phoronida, Entoprocta, Nemertea, Sipuncula, Mollusca, Echiura, Annelida incl. Pogonophora), (d) (possibly paraphyletic) Platyzoa (incl. "Platyhelminthes"-Catenulida, "Platyhelminthes"-Rhabditophora, Gastrotricha, Gnathostomulida, Micrognathozoa [see Kristensen and Funch 2000, Sørensen et al. 2000], Syndermata, Cycliophora, Myzostomida), and perhaps also (e) basalmost (paraphyletic?) assemblage including Mesozoa and "Platyhelminthes"-Acoelomorpha (see below). The groups of the most uncertain positions are Acoelomorpha (Platyzoa or basal Triploblastica?), Mesozoa (Platyzoa or basal Triploblastica?), Chaetognatha (Ecdysozoa?), and Ectoprocta (probably Lophotrochozoa).

Naturally, the $18 \mathrm{~S}$ rDNA is not a completely suitable candidate for reconstructing the evolutionary history of all metazoan phyla. Within the Metazoa, the current advantage of the $18 \mathrm{~S}$ rDNA sequences is predominantly in the representative taxonomical sampling. Almost all higher taxa of the Metazoa (except for Loricifera, Micrognathozoa, and few incertae sedis genera like Lobatocerebrum, Jennaria, and Buddenbrockia) are represented by at least one $18 \mathrm{~S}$ rDNA sequence. Although some authors have questioned whether the $18 \mathrm{~S}$ rDNA model may be biased due to variation in substitution rates (see e.g., McHugh 1998, Stiller and Hall 1999, Adoutte et al. 2000), this does not mean that ribosomal DNAs should not be used as a source of phylogenetic information, particularly when confronted and/or combined with other data, either molecular or morphological. So far, other molecules are all burdened by quite poor taxonomical sampling. Some of the above conclusions derived from combined ribosomalmorphological trees (e.g., monophyly of the Lophotrochozoa, less strongly also the monophyly of the Ecdysozoa) are supported also by analyses of the complete mitochondrial genomes (Stechmann and Schlegel 1999), Hox genes (de Rosa et al. 1999, Adoutte et al. 2000), elongation factor-1 $\alpha$ (McHugh 1997, Berney et al. 2000) and $\beta$-thymosin gene sequences (Manuel et al. 2000), as well as by distribution of unorthodox mitochondrial codons (Saito et al. 2000). Some others remain controversial. For example, the Acoelomorpha (see below) are either basalmost triploblasts as suggested by $18 \mathrm{~S}$ rDNA sequences (Zrzavý et al. 1998, Ruíz-Trillo et al. 1999; but see Giribet et al. 2000) and some ultrastructural and developmental data (see Raikova et al. 1998b, Reuter et al. 1998, Henry et al. 2000), or they belong to the derived platyhelminths according to elongation factor$1 \alpha$ sequences (Berney et al. 2000; but see Telford et al. 2000, Littlewood et al. 2001). 
A

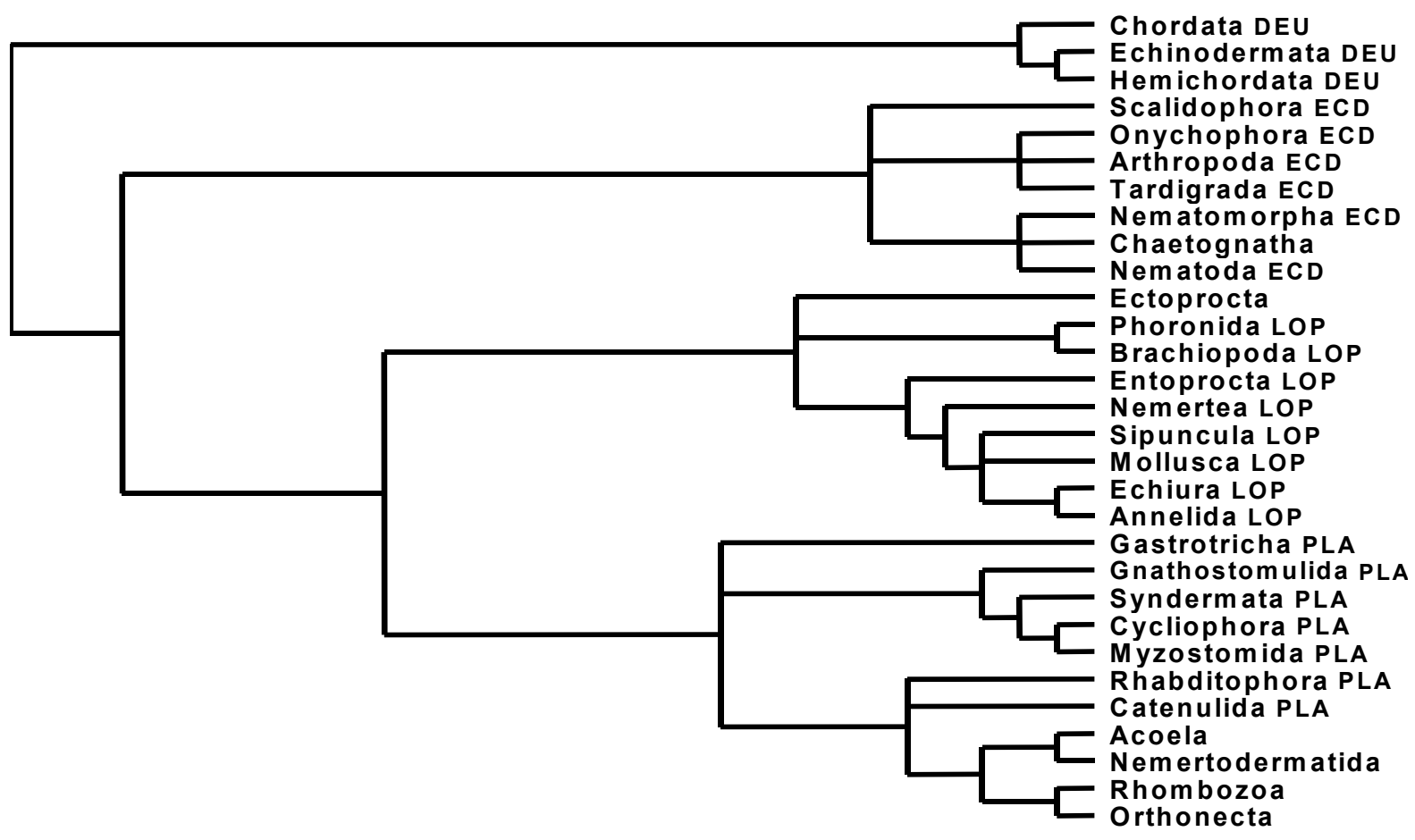

B

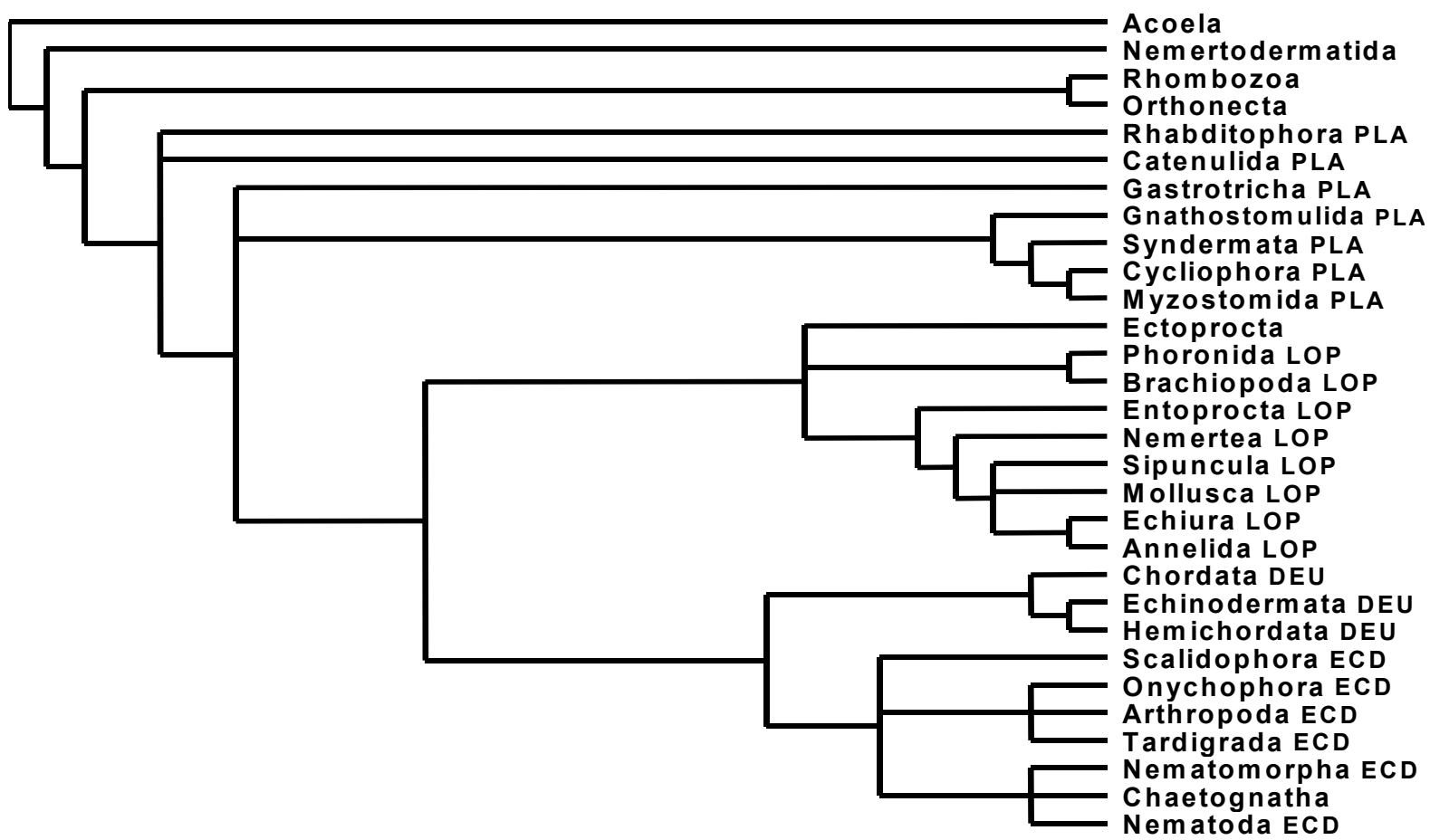

Fig. 1. Phylogenetic relationships within the Triploblastica based on combined morphological-molecular analyses (Zrzavý et al. 1998, 2001, Giribet et al. 2000). Both trees are identical and differ only in the root position: A - deuterostome-protostome rooting; B - within-platyzoan rooting. DEU - Deuterostomia, ECD - Ecdysozoa, LOP - Lophotrochozoa, PLA - Platyzoa; positions of the Acoela, Nemertodermatida, Mesozoa (=Rhombozoa + Orthonecta), Ectoprocta, and Chaetognatha are most problematic (see Giribet et al. 2000); "non-molecular" taxa (e.g., Micrognathozoa and Lobatocerebromorpha) excluded. 


\section{MYXOZOA AND POLYPODIUM}

Multicellular nature of the spores of the Myxozoa and the similarity of their polar capsules to the cnidarian nematocyst/cnidocyte system has repeatedly been recognised (recently by Siddall et al. 1995, Anderson 1998). Myxozoans were definitely found multicellular, with ontogeny proceeding to 4 or 5 differentiated cells stage; they also have the metazoan types of cell-to-cell junctions (including gap junctions) and collagencontaining extracellular matrix. Moreover, the detailed structure of the nematocyst-like capsule of the Myxozoa is shared exclusively with "higher", non-anthozoan cnidarians (=Medusozoa; =Tesserazoa; =Scyphozoa + Cubozoa + Hydrozoa): both the medusozoan nematocysts and myxozoan capsules have cnidocils (shortened, stiff, modified cilia lacking a basal rootlet), not unmodified mobile cilia as in the Anthozoa. The myxozoan capsules can easily be recognised as homologous to atrichous isorhizae, one of the nematocyst types present in all the cnidarian classes (see Schuchert 1993, Shostak and Kolluri 1995; see Xiao and Desser 2000).

Similarly as Myxozoa, some hydrozoan cnidarians are endoparasitic (Raikova 1994, Siddall et al. 1995). For example, Polypodium is adapted to intracellular parasitism in oocytes of acipenseriform fishes. Its earliest parasitic stages in previtellogenic oocytes are dikaryotic cells. The embryonic and postembryonic development up to the budding-stolon stage takes place inside fish oocytes. All parasitic stages are encircled by a polyploid unicellular trophamnion (= second polar body). At spawning, the stolons get into water, then they fragment into individual specimens that can move and feed, multiply by longitudinal fission, and form two kinds of endodermal gonads. One type of the gonads (two ovaria, each with a gonoduct, encircled with a common envelope) produce diploid cells that display no meiosis. The other gonads have no gonoducts, and their germ cells undergo two meiotic divisions; the entire gonad then becomes a gametophore with an ectodermal lid carrying nematocysts (exclusively of the atrichous isorhiza type; see Raikova 1990, Shostak and Kolluri 1995), and containing many dikaryotic cells. Gametophores are deposited onto the skin of juvenile fishes and then get into young fish oocytes (by an unknown transmission mode). Homology of Polypodium's life-cycle stages to the cnidarian life stage is uncertain; the free-living individuals are possibly homologous to the medusae (Raikova 1994).

Molecular data (18S rDNA, Hox genes) clearly indicate that myxozoans are metazoans (Smothers et al. 1994, Katayama et al. 1995, Schlegel et al. 1996, Anderson et al. 1998), and probably represent a sister group of Polypodium (Siddall et al. 1995, Zrzavý et al. 1998, Siddall and Whiting 1999; Fig. 2). Conflicting results of the molecular studies are probably caused by the "long-branch" nature of myxozoans and many other basal metazoans (e.g., Acoela, Mesozoa), and especially by poor taxonomical sampling in most molecular analyses. If the sample of cnidarians does not include Polypodium, the Myxozoa do not group with the Cnidaria but with basal triploblasts (as in Smothers et al. 1994, Katayama et al. 1995, Schlegel et al. 1996, Winnepenninckx et al. 1998b). Moreover, it has been recently acknowledged that the basal position of the Nematoda, putatively close to myxozoans in some molecular analyses, was an artifact caused by depauperate species sampling that had included exclusively the "long-branch", i.e. rapidly evolved, species of nematodes. In the presence of the "short-branch" nematode sequences (e.g., of Trichinella), all the Nematoda (including the "long-branch" species) are deeply nested within the Ecdysozoa (see below), but even the "shortbranch" nematodes included are unable to "carry" myxozoans into the intra-ecdysozoan position (see Zrzavý et al. 1998). Application of different treebuilding methods to the Myxozoa-Polypodium problem (Siddall and Whiting 1999), as well as combination of $18 \mathrm{~S}$ rDNA sequences with morphological characters (Siddall et al. 1995, Zrzavý et al. 1998) show that the Myxozoa-Polypodium clade is not an artifact caused by the "long-branch attraction" of aberrant 18S rDNA sequences. Both Myxozoa and Polypodium also share the exclusive armament by the atrichous isorhizae, fish parasitism, reduction of cilia, tubulocristate mitochondria, and dominating haplophase in their life cycles (see Raikova 1994, Seravin and Raikova 1994, Lom and Dyková 1997). Consequently, the cnidarian origin of the Myxozoa is the best supported hypothesis at present, based on ribosomal, morphological, and ecological data, while the "triploblast hypothesis" provides no explanation of the myxozoan ultrastructure and life strategy (see Siddall and Whiting 1999).

However, three interesting points should be mentioned. First, the ribosomal DNA analyses poorly resolve cnidarians (with or without myxozoans) as a monophyletic clade (Fig. 2). Instead, the Anthozoa (sometimes with Placozoa) form a basal metazoan branch, while scyphozoans, cubozoans, and hydrozoans (=Medusozoa s. str.) seem to be more closely related to the triploblasts, and the Polypodium-Myxozoa clade is the triploblast sister group (see Zrzavý et al. 1998, Siddall and Whiting 1999). Most probable, this topology is an artifact caused by accumulation of many "long branches" in this region of the tree. On the other hand, it is intriguing that Medusozoa s. str., Polypodium-Myxozoa, and Triploblastica share at least one derived ultrastructural character: the presence of gap junctions between adjacent cells (Nielsen 1995, Siddall et al. 1995, Lom and Dyková 1997). Moreover, the hypothesis that triploblasts are, cladistically, derived from the colonial Cnidaria (which are hence paraphyletic, compared with the triploblasts) has 
A

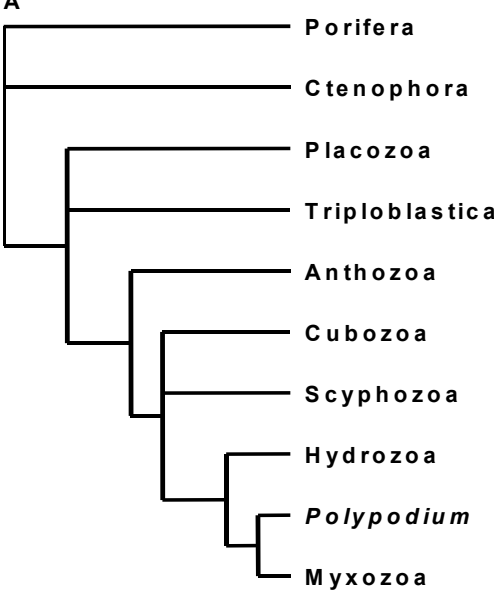

B

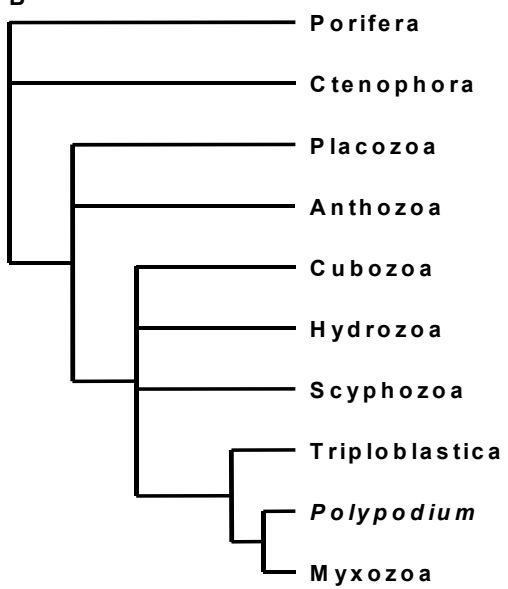

Fig. 2. Phylogenetic position of the Myxozoa within the Metazoa: A - with monophyletic Cnidaria (implying synapomorphic nematocysts, gap junctions convergent in Scyphozoa-Cubozoa-Hydrozoa-Polypodium-Myxozoa and in Triploblastica, organisation of the Antennapedia-class Hox genes convergent in Polypodium?-Myxozoa and in Triploblastica); B - with paraphyletic Cnidaria (implying synapomorphic gap junctions and organisation of the Antennapedia-class Hox genes, nematocysts lost in Triploblastica).

recently been formulated by Dewel (2000), on the basis of the developmental and palaeontological evidence. Second, the (taxonomically extremely depauperate) analysis of myxozoan Hox genes suggests that Myxozoa (Tetracapsula and Myxidium) are more closely related to triploblasts than to two hydrozoans, Hydra and Eleutheria (Anderson et al. 1998). This has been interpreted in terms of triploblast (possibly even deuterostome) non-cnidarian origin of the Myxozoa but the alternative hypothesis is possible: paraphyly of the Cnidaria in the relation to the Triploblastica (and the basalmost position of the Deuterostomia within the triploblasts). Third, systematic position of Polypodium within the Narcomedusae (Cnidaria: Hydrozoa) is uncertain and based predominantly on similarities in early development and on plesiomorphic characters (presence of atrichous isorhizae). Other characters of Polypodium, namely, bilateral body symmetry, the presence of gonoducts, and complete separation of epidermal and muscle cells (Raikova 1994) could also be assessed as triploblast-like features. Raikova (1994) has suggested (however, with no cladistic analysis) to elevate Polypodium to the level of a new class, Polypodiozoa.

The phylogenetic analysis of myxozoan taxa with known alternating life cycles ("myxosporean stage" from fish hosts versus "actinosporean stage" from annelid hosts) was recently provided by Xiao and Desser (2000), using Polypodium as an outgroup. The trees derived from the combined "myxosporean" and "actinosporean" ultrastructural data revealed that Myxozoa form four major clades (Ceratomyxa, Myxidium + Zschokkella, Myxobolus, Hoferellus +
Sphaerospora + Thelohanellus). The phylogenetic pattern indicates that the "actinosporean-stage" characters are more conservative than the characters of the "myxosporean stages". The $18 \mathrm{~S}$ rDNA phylogeny of the Myxozoa provides two clades, Ceratomyxa + Parvicapsula + Kudoa and Myxidium + Henneguya + Sphaerospora + Myxobolus + Thelohanellus (see Anderson et al. 1999, 2000, Kent et al. 2000). Recently, Kent et al. (2001) provide more comprehensive phylogeny of the Myxozoa, based on 18S rDNA characters (rooted to Polypodium). The tree includes the basalmost Malacosporea (see below) and the monophyletic Myxosporea that then split into Sinuoelinea-Ceratomyxa-Parvicapsula-Kudoa clade and the rest of myxosporeans (including species of Raabeia, Myxidium, Sphaerospora, Echinactinomyxon, Triactinomyxon, Myxobolus, Henneguya, Sphaeractinomyxum, Tetraspora, Endocapsula, Aurantiactinomyxon, Neoactinomyxon, Synactinomyxon, and Antonactinomyxon; note that "Myxidium", "Sphaerospora", "Triactinomyxon", "Myxobolus", "Henneguya", and "Aurantiactinomyxon" are polyphyletic assemblages of unrelated species). The $18 \mathrm{~S}$ rDNA tree is difficult to compare with the morpho-logical tree by Xiao and Desser (2000); however, it seems that the "actinosporean-stage" tree is more con-gruent to the molecular relationships than the "myxosporean" one (e.g., basal position of the ceratomyxid clade).

It is evident that myxozoan diversity is incompletely known. New discoveries include the basal Tetracapsula clade that includes also the proliferative kidney disease agent $(\mathrm{PKX}$ organism $=$ Tetracapsula bryosalmonae Canning, Curry, Feist, Longshaw et Okamura, 1999; 
syn. Tetracapsula renicola Kent, Khattra, Hedrick et Devlin, 2000) from salmonid fish (Anderson et al. 1999, Canning et al. 1999, 2000, Saulnier et al. 1999, Kent et al. 2000). The primary hosts of Tetracapsula species, in which they undergo a sexual phase, are phylactolaemate bryozoans. It develops in the bryozoan coelomic cavity as freely floating sacs containing two types of cells, stellate cells and sporoplasmogenic cells, which become organised as spores. Eight stellate cells differentiate as four capsulogenic cells and four valve cells that surround a single sporoplasmogenic cell. The sporoplasmogenic cell undergoes meiosis and cytoplasmic fission to produce two sporoplasms with haploid nuclei. Sporoplasms contain secondary cells. Tetracapsula diverged early in the evolution of the Myxozoa, before the radiation that gave rise to the better known genera belonging to the Myxosporea. The genus Tetracapsula shares both "myxosporean"-phase and "actinosporean"phase characters of the Myxosporea. Unique features of the Tetracapsula clade are the phylactolaemate-(-fish) cycle, sac-like proliferative body, valve cells not covering the exit point of the polar filament, lack of a stopper-like structure scaling the exit, maintenance of valve cell integrity even at spore maturity, absence of hardened spore walls, and unique structure of sporoplasmosomes in the sporoplasms (with lucent bar-like invaginations). A new class Malacosporea (with order Malacovalvulida) has recently been proposed by Canning et al. (2000) to accommodate the Tetracapsula species. It is proposed that the bryozoan-salmonid cycle in Malacosporea is homologous to the annelid-fish alternation in the Myxosporea. The comparison with the Polypodiozoa suggests that the fish hosts are primitive for the myxozoan life cycles, another indication that salmonids are not accidental, dead-end hosts for Tetracapsula species (Kent et al. 2000).

\section{MESOZOA}

The enigmatic mesozoans remain the only "phylumlevel" parasitic metazoan group whose free-living relatives are not known. The matter of mesozoan monophyly has rarely been critically examined by zoologists who either used "Mesozoa" as an operational unit the monophyly of which is not tested, or doubted its monophyly merely because the two subgroups, Orthonecta and Rhombozoa (=Dicyemida s. lat.), are too different. Only two morphological cladistic analyses (Ax 1996, Zrzavý et al. 1998) treat both mesozoan groups as separate taxonomical units, and both found them to form a clade. Molecular phylogeneticists initially refuted the mesozoan clade (Hanelt et al. 1996, Pawlowski et al. 1996), but subsequent, more comprehensive studies suggested that also $18 \mathrm{~S}$ rDNA sequences support the monophyly of Mesozoa (see Winnepennickx et al. 1998b, Zrzavý et al. 1998, Siddall and Whiting 1999; Fig. 1). Their monophyly is supported by many characters, e.g., overall body architecture (multiciliated epidermis and interior nondigestive gamete-producing tissue), a unique type of ciliary rooting with single rootlets lying horizontally under the cell surface and pointing towards the animal's front, reduction of muscular, nervous, and sensory systems, and reduction or loss of extracellular matrix and zonulae adhaerentes (Ax 1996, Cavalier-Smith 1998a, Zrzavý et al. 1998).

There is a wide consensus that Mesozoa belong to the Metazoa (Cavalier-Smith et al. 1996, CavalierSmith 1998a, Ax 1996), most probably to primitive triploblasts (Katayama et al. 1995, Hanelt et al. 1996, Pawlowski et al. 1996, Furuya et al. 1996, 1997, Winnepenninckx et al. 1998b, Zrzavý et al. 1998, Siddall and Whiting 1999). Bilateral body symmetry, presence of muscle-like fibres (in orthonectids), mode of the oogenesis, ciliary rootlet system, orientation of the flagellar basal bodies, and presence of the septate and gap junctions between epithelial cells substantiate the triploblast origin of the mesozoans. The fact that mesozoan mitochondrial cristae are tubular and not flat, which was previously used as evidence of their "protozoan" origin (Cavalier-Smith 1983, 1993), was subsequently dismissed as a sufficient reason for excluding the Mesozoa from metazoans (Cavalier-Smith et al. 1996, Cavalier-Smith 1998a). Nevertheless, both the mesozoan clades are extremely autapomorphic in most morphological and developmental respects (Slyusarev 1994, 2000, Czaker 1994, 2000, Ax 1996, Horvath 1997, Slyusarev and Miller 1998) as well as in the molecular characters (Aleshin et al. 1999, Watanabe et al. 1999). Ax (1996) did not find any characters indicating sister-group relationships of the Mesozoa within triploblasts: only the Neodermata (flukes, tapeworms, and relatives), nested within the rhabditophoran flatworms (see below), share the structure of ciliary rootlet system with the mesozoans.

Molecular analyses (e.g., Eernisse 1997, Zrzavý et al. 1998, Siddall and Whiting 1999) do not exclude close relationships between mesozoans and acoelomorphan flatworms (=Acoela + Nemertodermatida). Both Mesozoa and Acoelomorpha then represent the basalmost triploblast phyla (traditional "Platyhelminthes" are then not monophyletic; see Katayama et al. 1996, Eernisse 1997, Zrzavý et al. 1998, Littlewood et al. 1999a, RuízTrillo et al. 1999). The previous results that suggest close relationship between nemertodermatids and some rhabditophoran flatworms and hence the polyphyly of the Acoelomorpha (see Zrzavý et al. 1998, Littlewood et al. 1999a, Ruíz-Trillo et al. 1999, Littlewood and Olson 2001) were based on the 18S rDNA sequence of putative Nemertinoides elongatus whose aberrant behaviour is most probably caused by misidentification with a proseriate flatworm (Giribet et al. 2000, Jondelius et al. 2000, Littlewood et al. 2001). The 
within-rhabditophoran placement of nemertodermatids is not supported by $28 \mathrm{~S}$ rDNA analysis (Litvaitis and Rohde 1999), nor by morphology (Ax 1996, Lundin and Hendelberg 1998, Zrzavý et al. 1998, Littlewood et al. 1999a, Raikova et al. 2000, and reference therein), nor by mitochondrial genetic codes (Telford et al. 2000), nor by the analysis including $18 \mathrm{~S}$ rDNA sequence of other nemertodermatid species (Jondelius et al. 2000). They all agree that Nemertodermatida are basal triploblasts, probably related to the Acoela.

The close relationship between Acoelomorpha and Mesozoa and the basal position of both groups within the Triploblastica are supported by a few morphological characters. They both share weakly developed (reduced?) or absent (lost?) extracellular matrix and zonulae adhaerentes (Ax 1996, Cavalier-Smith 1998a, Zrzavý et al. 1998). The present immunohistochemical data suggest that the Acoela have neither true orthogonal nervous systems nor true brains but a variable number of longitudinal nerve cords and a symmetrical brain-like structures lacking a neuropile and composed of commissural fibres associated with a few cell bodies (Haszprunar 1996a, b, Raikova et al. 1998b, Reuter et al. 1998, Ruíz-Trillo et al. 1999); Nemertodermatida have neither a "commissural brain" similar to that of the Acoela, nor a true ganglionic brain and orthogon (Raikova et al. 2000); Mesozoa lack the nervous system at all. The sperm type of the Nemertodermatida probably has evolved from the primitive metazoan sperm rather than from an aberrant biflagellar sperm type as found in many other flatworms (Lundin and Hendelberg 1998); there are also ultrastructural details indicating that the sperm type of the Acoela is not homologous to that of other flatworms (Justine et al. 1998, Raikova et al. 1998a, Raikova and Justine 1999). The acoelomorphan and rhabditophoran flatworms, and some Lophotrochozoa (Lobatocerebrum, entoproct larvae, and nemerteans) have the frontal-gland system (Ehlers 1992, Haszprunar 1996b) which is possibly homologous to the frontal receptor present in the orthonectid Mesozoa (Slyusarev 1994). If the Acoelomorpha are basalmost triploblasts, true brain, true nervous orthogon, hindgut-anus system, and protonephridia are primitively absent in both Acoelomorpha and Mesozoa; if the deuterostome-protostome rooting is preferred, monophyly of the Acoelomorpha + Mesozoa is further supported by the lost of these four traits. In the total-evidence (18S rDNA + morphology) analysis of the relationships of metazoan phyla (Zrzavý et al. 1998), Acoela, Mesozoa, and Nemertodermatida represent either successive outgroups ("phyla") of all other Triplo-blastica (see also Littlewood et al. 1999a, b, Jondelius et al. 2000).

The basal position of the Acoelomorpha and Mesozoa is not generally accepted. Several molecular analyses based on both 18S rDNA (Campos et al. 1998,
Jondelius 1998, Winnepenninckx et al. 1998b, Giribet et al. 2000) and elongation factor- $1 \alpha$ amino acid sequences (Berney et al. 2000) show that acoelans and mesozoans, respectively, belong into (or close to) the Rhabdito-phora. Giribet et al. (2000) have analysed the same morphological dataset as Zrzavý et al. (1998) together with $18 \mathrm{~S}$ rDNA sequences of many triploblasts (excluding Mesozoa) with a similar conclusion: Acoela belong to the Rhabditophora while position of the Nemertodermatida is uncertain. On the contrary, the analysis of the mitochondrial genetic codes of the flatworms (Telford et al. 2000) shows that all Rhabditophora have two unorthodox codons $(\mathrm{AAA}=\mathrm{Asp}, \mathrm{AUA}$ = Ile), while Acoela, Nemertodermatida, Mesozoa (Rhombozoa), and Catenulida all share the plesiomorphic (orthodox) genetic code. Telford et al. (2000) do not resolve the phylogenetic position of these four groups but strongly support monophyly of the Rhabditophora: neither acoels, nor nemertodermatids, nor mesozoans belong among the rhabditophoran flatworms. More comprehensive sampling of flatworm elongation factor- $1 \alpha$ sequences (Littlewood et al. 2001) suggests that putative insertion shared by Acoela (Convoluta roscoffensis) and Tricladida (Rhabditophora) is not present in other acoels, and that elongation factor- $1 \alpha$ alone is a poor indicator of phylogenetic relationships at a metazoan level.

Kobayashi et al. (1999; see de Rosa et al. 1999, Rokas and Holland 2000) published a sequence of the Hox gene (DoxC) from Dicyema (Mesozoa: Rhombozoa). This gene includes a diagnostic "spiralian" motif (seven amino acids), reported only from the Antennapedia orthologues in the Spiralia, i.e., Lophotrochozoa (annelids, nemerteans, brachiopods) and Platyzoa (rhabditophoran flatworms). However, this "diagnostic" motif could be shared also by acoelomorphans (unknown) and/or represent an ancestral triploblast condition: while "diploblasts" do not have the Antennapedia subgroup of Hox genes, all triploblasts have these genes, and some amino-acid sequence has to be plesiomorphic (see Telford 2000). Moreover, analysis of amino-acid sequences includes intrinsic convergence problems (Simmons 2000): if AAA is changed to AAC in one clade and AAA to AAT in the other, both clades would appear to share Lys $\rightarrow$ Asn, although there is no actually shared evolutionary event. This intrinsic convergence problem applies to 12 of 20 amino acids.

The above hypotheses seem to include almost no consensus. However, the major difference among them depends on deuterostome-protostome versus withinplatyzoan rooting of the tree (Fig. 1). Besides the root position, almost all trees listed above include "convex" (= either monophyletic or paraphyletic but nonpolyphyletic) Deuterostomia, Lophotrochozoa, Ecdysozoa and Platyzoa (that would include also Acoelomorpha and Mesozoa). The only exceptions are some 
ribosomal, morphological, and combined ribosomalmorphological studies (e.g., Littlewood et al. 1999a, b, Ruíz-Trillo et al. 1999) suggesting that acoelomorphans and other platyhelminths are isolated from each other by non-platyzoan taxa (e.g. by deuterostomes). The withinplatyzoan rooting is compatible with ancestral position of the Acoelomorpha and Mesozoa in most 18S rDNA and combined studies (Littlewood et al. 1998a, b, Zrzavý et al. 1998, Ruíz-Trillo et al. 1999), with the platyhelminth affinities of (some) Acoela based on elongation factor-1 $\alpha$ (Berney et al. 2000), with the platyhelminth affinities of Acoela and Mesozoa in few $18 \mathrm{~S}$ rDNA and combined analyses (see Winnepenninckx et al. 1998b, Giribet et al. 2000), with the basal position of a rhabditophoran flatworm (Schistosoma) in a simultaneous analysis of ten protein sequences (Hausdorf 2000), and with the presence of the "spiralian" motif in the mesozoan Hox gene (Kobayashi et al. 1999). The combined analysis of morphology, 18S rDNA, 28S rDNA, Hox, cytochrome oxidase subunit I (COI), and elongation factor-1 $\alpha$ (J. Zrzavý, unpubl.) supports two monophyletic sister groups of the Triploblastica, (Acoelomorpha + Mesozoa) and Eutriploblastica, the latter with paraphyletic "Platyzoa" at the eutriploblast base, and with the monophyletic clade (Lophotrochozoa (EcdysozoaDeuterostomia)).

By all means, the mesozoans represent secondarily simplified triploblast animals of the flatworm-like grade, and they are not primitive "missing link between the Protozoa and Metazoa" as older authors often suggested (recently Czaker 2000). The endoparasitism within triploblast hosts is a further possible synapomorphy of the Rhombozoa and Orthonecta. However, the homology of their modes of endoparasitism is quite doubtful: orthonectids have immobile tissue-parasitic stages within many marine metazoans and mobile freeliving sexual stages (Kozloff 1994, Slyusarev and Miller 1998). The orthonectids seem to parasitise predominantly polychaetes as well, only some Rhopalura (s. lat.) species live also in molluscs, nemerteans, flatworms, and echinoderms. The Rhombozoa are mobile parasites within the nephridia of cephalopods. Both life-history modes are extremely autapomorphic and cannot be easily derived one from another. It is possible to infer that all the mesozoans are primary parasites of the lophotrochozoan subclade that includes annelids, molluscs, and/or nemerteans, and that some less host-specific orthonectids secondarily invaded also few platyzoans (Slyusarev and Miller 1998), few deuterostomes (Deheyn et al. 1998), but apparently not any ecdysozoans.

\section{PARASITIC FLATWORMS: NEODERMATA, REVERTOSPERMATA, MEDIOFUSATA}

Almost all modern phylogenetic analyses of platyhelminth relationships accord that Rhabditophora is a monophyletic clade (separate "phylum" according to Zrzavý et al. 1998), including flukes, tapeworms, and most free-living flatworms except for Acoelomorpha and Catenulida (Ax 1996 and references therein, Zrzavý et al. 1998, Littlewood et al. 1999a, b, Littlewood and Olson 2000). The conflicting views concerning the phylogenetic position of the Acoela and especially Nemertodermatida (both groups sometimes grouped with[in] the Rhabditophora forming the latter group paraphyletic; see Campos et al. 1998, Jondelius 1998, Littlewood et al. 1999b, Giribet et al. 2000) were discussed above. Nonetheless, the close relationships of all the rhabditophoran groups, Macrostomomorpha (=Haplopharyngida + Macrostomida), Polycladida, Lecithoepitheliata (=Gnosonesimidae + Prorhynchidae), and Neoophora s. str., remain the most reliable hypothesis. The monophyly of the Neoophora (flatworms with the ectolecithal, "multicellular" eggs, and their parasitic descendants; with or without Lecithoepitheliata) is only rarely recovered by the cladistic studies (see Littlewood et al. 1999a, b, Littlewood and Olson 2001).

The monophyly of one of the neoophoran subclades that includes most parasitic flatworms, the Neodermata (=Aspidogastrea + Digenea + Monogenea + Gyrocotylida + Amphilinida + Eucestoda), is now considered as beyond doubt (Fig. 3). It is supported by replacement of the larval epidermis by the neodermis with insunk nuclei, lack of vertical ciliary rootlets of epidermal cilia, protonephridial flame bulbs formed by two cells, presence of a characteristic electron-dense collars of sensory receptors, sperm axonemes incorporated in sperm body by proximo-distal fusion, and incorporation of vertebrate host in the life cycle.

The Trematoda (= Aspidogastrea + Digenea) is the sister group of all other neodermatans (=Cercomeromorpha) including the Monogenea (=Monogenoidea) and Cestoda (=gyrocotylid-amphilinid-eucestode clade). However, the 18S rDNA studies show that the Monogenea may well be paraphyletic compared with the cestodes, with the basal Polyopisthocotylea and with Monopisthocotylea as a cestode sister group (Trematoda (Polyopisthocotylea (Monopisthocotylea-Cestoda))) (Littlewood et al. 1999b, Litvaitis and Rohde 1999, Littlewood and Olson 2000). Alternatively, the 28S rDNA sequences (Mollaret et al. 1997) suggest even more basal position of the paraphyletic monogeneans and paraphyletic Cercomeromorpha: (Monopisthocotylea (Polyopisthocotylea (Trematoda-Cestoda))). Although the combined morphological-molecular analyses show the Cercomeromorpha and Monogenea monophyletic (Littlewood et al. 1999a, b), the question is far from being resolved (see Boeger and Kritsky 2001, Littlewood and Olson 2001). Phylogenetic analysis of $18 \mathrm{~S}$ rDNA and 28S rDNA sequences, as well as ultrastructural studies concerning sensory receptors, 


\section{A}

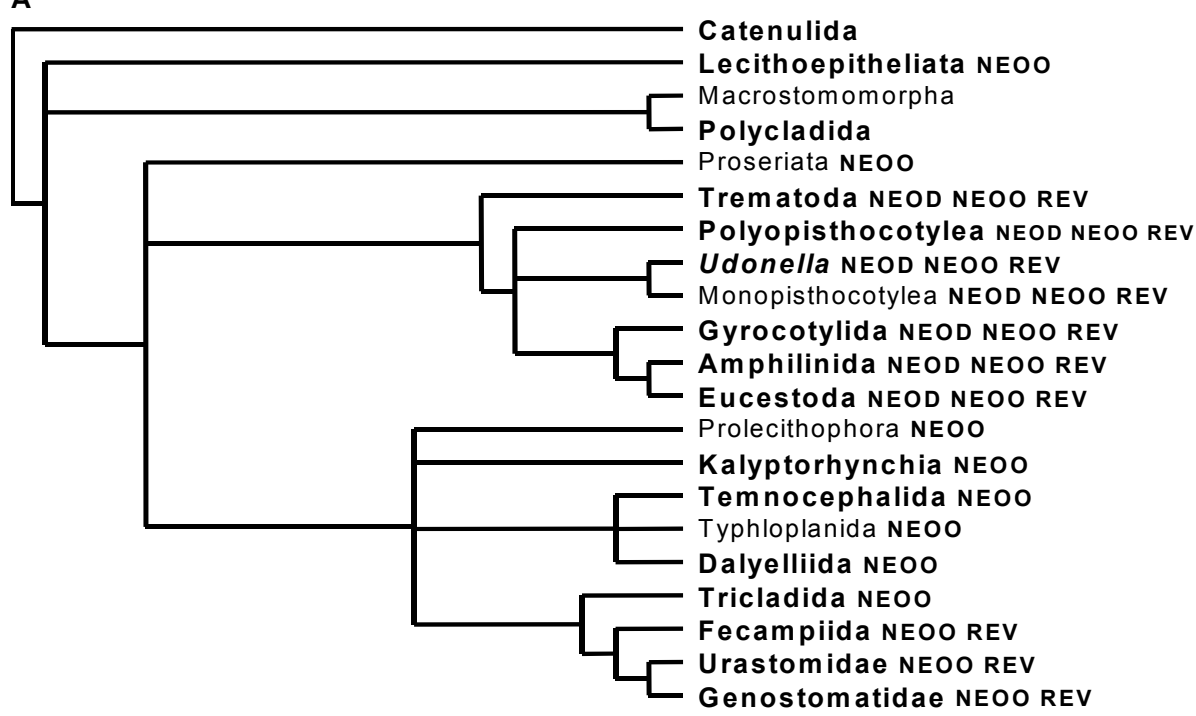

B

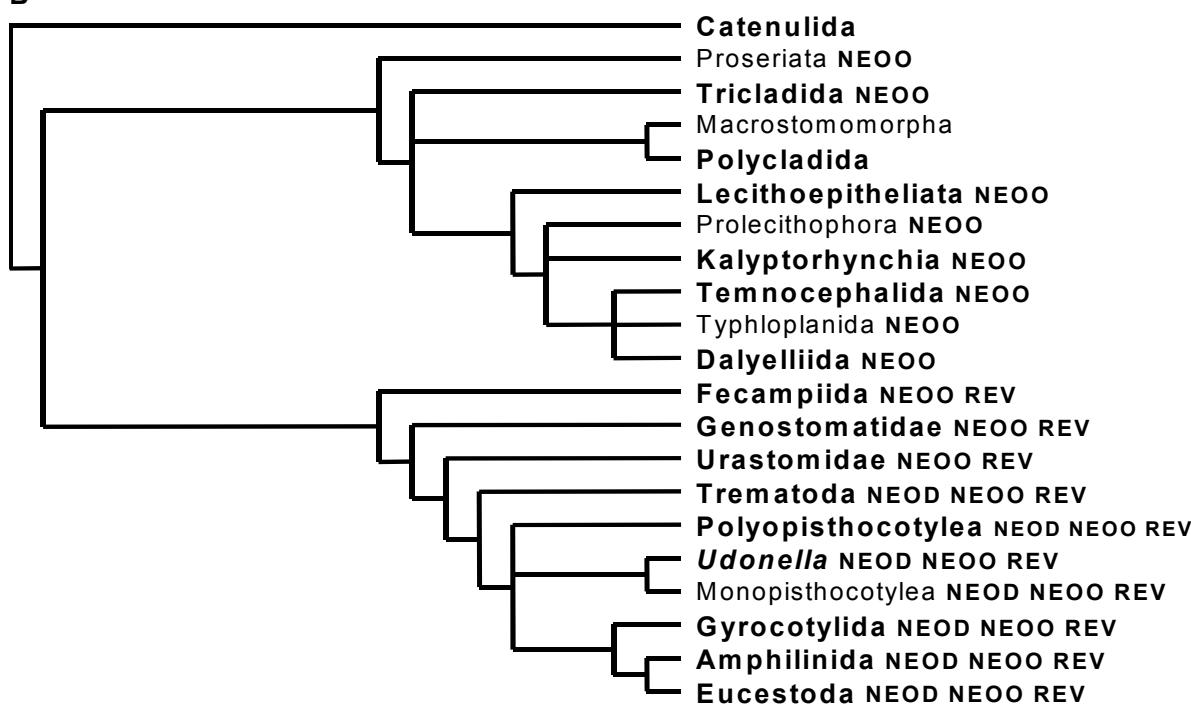

Fig. 3. Phylogenetic position of the Neodermata within the Platyhelminthes (Acoelomorpha excluded): $\mathbf{A}$ - tree derived from combined morphological-18S rDNA and morphological-18S rDNA-28S rDNA analyses; B - morphological tree with monophyletic Revertospermata (both modified from Littlewood et al. 1999a, b). NEOO - Neoophora, NEOD - Neodermata, REV - Revertospermata, possibly non-monophyletic taxa are not boldfaced.

neodermis, sperm structure, and spermiogenesis place the enigmatic Udonella (an ectoparasite of copepod and branchiuran crustaceans) firmly as a monopisthocotylean monogenean with secondarily reduced cercomere, not as a sister group to the Neodermata (Littlewood et al. 1998a, 1999a, b, Mollaret et al. 2000, Boeger and Kritsky 2001; but see Zamparo et al. 2001).

The sister-group relationships of the Neodermata is uncertain. Traditionally, the Neodermata were regarded as nested within the neoophoran "turbellarians", with some "dalyelloids" and/or temnocephalids representing the neodermate sister group. However, this is not supported by the molecular data which indicate a more basal position of the Neodermata within the Rhabditophora. The 18S rDNA tree (Littlewood et al. 1999b) shows that Lecithoepitheliata, (most) Proseriata, and a huge clade including Tricladida and most "rhabdocoels" are successive outgroups to the Neodermata; in the combined tree, the clade including all neoophoran "turbellarians" is the neodermate sister group. Later, the "conditional combination" of $18 \mathrm{~S}$ rDNA and morphological data (Littlewood et al. 1999a) 
suggests that Neoophora except for Lecithoepitheliata and Proseriata form the sister group of the Neodermata (the basal position of the paraphyletic "Proseriata" is also supported by Littlewood et al. 2000). Finally, analysis of 270 platyhelminth 18S rDNA sequences (Littlewood and Olson 2001, see also Baguñà et al. 2001) shows that Neodermata are a sister group of most other Neoophora (that are further split into three subclades, Proseriata, most "rhabdocoels", and Prolecithophora-Tricladida-Fecampiida-Urastomidae), while Lecithoepitheliata and Macrostomomorpha-Polycladida are more basal rhabditophoran branches (i.e., lecithoepitheliates are not neoophorans). All this rejects the hypothesis that Temnocephalida (ectocommensals of crustaceans and molluscs) and/or Fecampiida (endoparasites of crustaceans and polychaetes) are closely related to the Neodermata. Instead, they are both placed within the major "Neoophora" clade, temnocephalids close to the Typhloplanida and Dalyelloida, fecampiids close to the Tricladida, Urastomidae, and sometimes also Prolecithophora (Littlewood et al. 1999a, b, Littlewood and Olson 2001). Neither Cercomeria (=Temnocephalida + Cercomeromorpha) nor Cercomeridia (=Cercomeromorpha less Udonella; see Zamparo et al. 2001) are monophyletic.

On the contrary, new ultrastructural evidence revives the hypothesis that some parasitic "turbellarians" may be closely related to the Neodermata. Notentera is a recently discovered polychaete gut parasite, with no mouth, pharynx, or intestine; the dorsal epidermis of adult animals forms a thick pad that is very similar to gut epithelia. Structure of ciliary rootlets and dermal glands point to close relationships with the Fecampiidae $(=$ Kronborgia + Glanduloderma + Fecampia $)$. The course of spermiogenesis and the mature sperm's axoneme ultrastructure are very similar to that of the Neodermata. It has been suggested that all platyhelminths with neodermatan type of spermiogenesis (all commensal/parasitic: Fecampiida [=Fecampiidae + Notenteridae], Genostomatidae [=Genostoma + Ichthyophaga], Urastomidae [=Urastoma], and Neodermata) form a monophyletic group, the Revertospermata, which further splits into Fecampiida and Mediofusata (=Genostomatidae + Urastomidae + Neodermata) (Watson 1997, Joffe and Kornakova 1998, 2001, Kornakova and Joffe 1999). More comprehensive morphological analysis by Zamparo et al. (2001) supports the clade of (Neodermata (FecampiidaeUrastoma)). However, combination of ribosomal sequences with the morphological dataset corrected according to Kornakova and Joffe (1999) still does not support the homology of fecampiid, urastomid, and neodermatan sperm ultrastructure (Littlewood et al. 1999a, b). The most inclusive combined analysis (18S rDNA $+28 \mathrm{~S}$ rDNA + morphology) identifies the fecampiid-urastomid-genostomatid-tricladid clade as a sister group of the Neodermata (Littlewood et al. 1999a, p. 267).

In summary, two alternative sister groups of the Neodermata are possible: strong ultrastructural evidence suggests the Fecampiida, Genostomatidae, and Urastomidae, whilst the molecules (even if combined with morphological characters) suggest a more inclusive neoophoran clade (at least Fecampiida + Genostomatidae + Urastomidae + Tricladida). Naturally, this would have a profound influence on the hypotheses about the evolution of neodermatan parasitism (see Littlewood et al. 1999b). It is most probable that the ancestor of Neodermata was an endoparasite of vertebrates and only Monogenea (including Udonella) moved towards ectoparasitism (while retaining the neodermis). This scenario is, however, somewhat weakened by the possible paraphyly of the monogeneans - ancestral ectoparasitism and parallel shifts to the endoparasitism would then be more probable. The intermediate hosts, molluscs in Trematoda and crustaceans in Amphilinidea + Eucestoda (+ Gyrocotylidea?) are evidently apomorphic for the respective clades (but see Zamparo et al. 2001). Despite of the uncertain ancestral ecto/endoparasitic life strategy, the phylogeny of Neodermata suggests that one-host cycle involving only the vertebrate is the ancestral condition. It is important to emphasise that the general belief in "invertebrate host $\rightarrow$ vertebrate host" transition is often not substantiated by anything but subliminal anthropocentrism.

\section{ACANTHOCEPHALA AND SEISON}

It is long acknowledged that Acanthocephala and Rotifera are closely related to each other (Lorenzen 1985, Nielsen 1995, Wallace et al. 1996), forming the clade of Syndermata (Ahlrichs 1997, 1998; =Trochata; Cavalier-Smith 1998a). Monophyly of the Syndermata (Fig. 4) is supported by the syncytial integument with an intrasyncytial skeletal lamina (the intracellular skeleton within the non-syncytial epidermis shared also with Micrognathozoa), by the basal body of cilia being formed from microtubular singlets or doublets (not triplets), by the jaws with tube-like support rods composed of lucent material surrounding an electrondense core, the jaws being attached to cross-striated pharyngeal muscles by epithelial cells (shared with the Gnathostomulida and Micrognathozoa, secondarily absent in acanthocephalans), by the anteriorly directed sperm flagellum (shared with Myzostomida), by the primordial germ cells invaginated separately before gastrulation, and by loss of the cilia of the protonephridial canal cells (see Clément and Wurdak 1991, Ahlrichs 1993, 1997, 1998, Nielsen 1995, Rieger and Tyler 1995, Garey et al. 1996, 1998, Albrecht et al. 1997, Kristensen and Funch 2000, Sørensen 2000, Sørensen et al. 2000). 
A

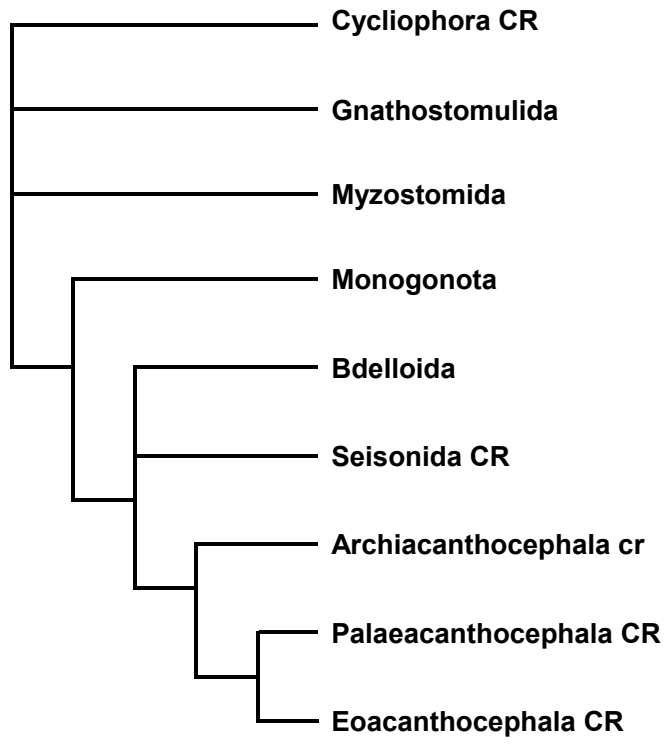

B

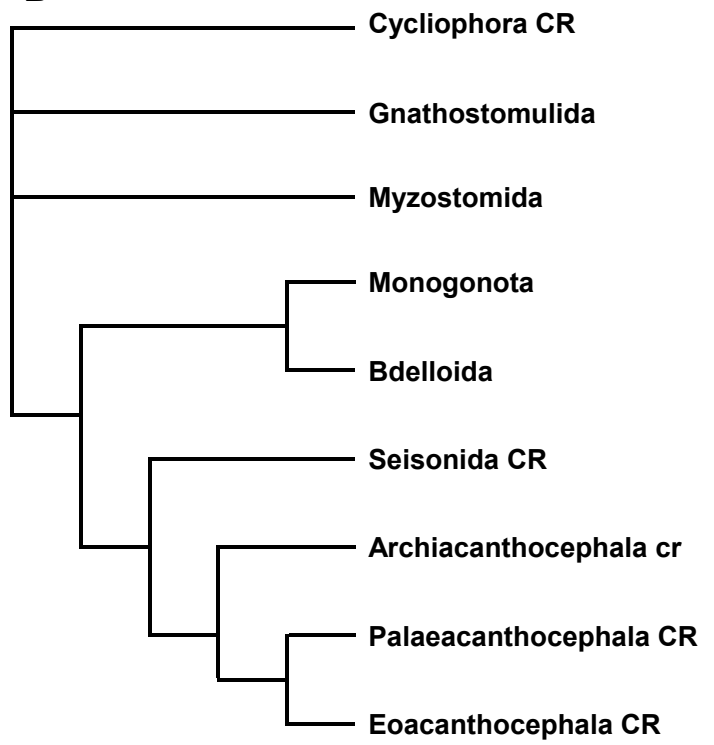

Fig. 4. Phylogenetic position of the Acanthocephala and Seisonida within the Syndermata: A - with paraphyletic Eurotatoria (= Monogononta + Bdelloida; combined morphological-18S rDNA analysis; two different alignments with substitution to gap cost ratio $3: 4$ and $3: 5$, respectively, the variable and "ambiguously aligned" positions were extracted by "culling" both alignments; see Gatesy et al. 1993, Wheeler et al. 1995; in the combined datasets, morphological characters were weighted as gaps, i.e. sequence characters, gaps, and morphology were weighted as $3: 4: 4$ and $3: 5: 5$, respectively); B - with monophyletic Eurotatoria and Pararotatoria comb. n. (combined analysis of morphology and hsp 82 and 18S rDNA sequences). Micrognathozoa (probably a sister group of the Syndermata) not included. The affinity to crustacean hosts is indicated by CR (cr = Hexapoda as possibly modified crustaceans).

Since Lorenzen (1985), the acanthocephalans are increasingly regarded as the rotifer ingroup rather than sister group of the monophyletic Rotifera. The Bdelloida is the rotifer group that has been hypothesised as a possible acanthocephalan sister group (based on the shared lemnisci and proboscis); however, true homology of the putative bdelloid-acanthocephalan synapo-morphies has been doubted (Nielsen 1995, Ricci 1998). In the initial molecular (18S rDNA) studies, acantho-cephalans represented aberrant endoparasitic rotifers close to Philodina acuticornis (Bdelloida), and the monophyly of Lemniscea (=Bdelloida + Acanthocephala; Garey et al. 1996, Eernisse 1997, Zrzavý et al. 1998) seemed to be strongly indicated (see also Garey et al. 1998: 18S rDNA + 16S rDNA). However, the sequence of the third rotifer group, the Seisonida, was lacking at that time, and the remaining two groups, Monogononta and Bdelloida, were represented by a single species each. The phylogenetic position of the Seisonida became more interesting after detailed ultrastructural studies by Ahlrichs (1993, 1997, 1998) that revealed obvious acanthocephalan-like features in Seison spermatozoa and integument (see Ahlrichs 1998, Garey et al. 1998, Ferraguti an Melone 1999). So far, the seisonids were regarded either as basalmost rotifers (Pararotatoria vs. Eurotatoria, the latter group including monogononts and bdelloids), because of their poorly developed rotatory organs, spermatozoa with acrosomes, and a weak sexual dimorphism (see also Kristensen and Funch 2000, Sørensen et al. 2000), or as aberrant monogononts (Clément 1993).

In more recent analyses, the phylogenetic pattern within the Syndermata remains obscured. Seison seems to be closely related to the bdelloid Philodina acuticornis and both together are the sister group of the Acanthocephala (=Lemniscea s. lat.; Zrzavý et al. 2001: $18 \mathrm{~S}$ rDNA + morphology); on the other hand, Eurotatoria (=Monogononta + Bdelloida) seems to form a clade (Garcia-Varela et al. 2000: 18S rDNA; Welch 2000: $h s p 82$ gene). In the present paper, reanalysis of available $18 \mathrm{~S}$ rDNA sequences, together with morphological characters by Zrzavý et al. (2001) was performed. It suggests that the $18 \mathrm{~S}$ rDNA sequences of Philodina spp. display an aberrant behaviour $-P$. roseola is nested within the monogonont genus Brachionus, while $P$. acuticornis is, together with Seison, related to acanthocephalans. Otherwise, the basal topology is (Monogononta (Seisonida-Acanthocephala)). If both Philodina species are excluded from the $18 \mathrm{~S}$ rDNA analysis, this topology is retained; if a strict consensus of the Philodina sequences is constructed, this "hybrid" sequence is placed among the Brachionus species. Separate analysis of the hsp82 sequences (unrooted because there are no available $h s p 82$ sequences from 
the possible syndermate close outgroups) provides two nonpolyphyletic, "convex" groups, Seisonida + Acanthocephala and Monogononta + Bdelloida (both eurotatorian groups are "convex" as well). If the analysis is limited to the four species from which both $18 \mathrm{~S}$ rDNA and hsp82 sequences are known (Brachionus plicatilis, Philodina roseola, Seison sp., and acanthocephalan Moniliformis moniliformis), two topologies emerge: (Seisonida (Acanthocephala (Monogononta-Bdelloida))) if the morphology is not included (compare Kristensen and Funch 2000, Sørensen et al. 2000), and ((Seisonida-Acanthocephala) (Monogononta-Bdelloida)) if it is included. All this indicates that phylogeny of the Syndermata is far from being well understood (Fig. 4; see also Miquelin et al. 2000). The monophyly of the Seisonida + Acanthocephala appears well supported by morphological data and possibly also by $18 \mathrm{~S}$ rDNA sequences (the name Pararotatoria comb. n. is possibly useful for this clade). Hypothesis on the monophyly of the Lemniscea (=Bdelloida + Acanthocephala + Seisonida?) is probably falsified.

Phylogenetic relationships within the Acanthocephala seem to be well resolved. They are currently divided into three major taxonomical groups, Archiacanthocephala, Palaeacanthocephala, and Eoacanthocephala, distinguished by location of lacunar canals, persistence of ligament sacs in females, number and type of cement glands in males, number and size of proboscis hooks, host taxonomy and ecology. The analyses based on $18 \mathrm{~S}$ rDNA sequences and morphology show that Archi-acanthocephala is the sister group (or paraphyletic stemline) to a clade including Eoacanthocephala + Palaeacanthocephala (Near et al. 1998, Garcia-Varela et al. 2000, Herlyn 2001, Monks 2001; Fig. 4).

The phylogenetic pattern indicates that there are two acanthocephalan clades, one inhabiting mostly hexapod intermediate hosts and terrestrial tetrapods as definitive hosts (Archiacanthocephala), the other crustacean intermediate hosts and various vertebrate definitive hosts (Eoacanthocephala + Palaeacanthocephala). The probable sister-group relationship between seisonids (epibionts on leptostracan crustaceans) and acanthocephalans suggests that crustacean affinity is primitive for the Acanthocephala; the Cycliophora, recently recognised as syndermate relatives (Winnepennickx et al. 1998a, Giribet et al. 2000, Zrzavý et al. 2001; but see Sørensen et al. 2000), are crustacean epibionts as well (Fig. 4). Moreover, there is a growing consensus that the hexapods are closely related to (or derived from) the Crustacea (see Regier and Shultz 1997, 1998, Zrzavý et al. 1997, Edgecombe et al. 2000, Giribet and Ribera 2000, Shultz and Regier 2000). The arthropod intermediate-host distributions are more consistent with monophyletic groups of the Acanthocephala than the vertebrate definitive-host distributions that display independent radiations into similar hosts (Near et al. 1998). It is then possible that the functional relationships of acanthocephalan larvae with their crustacean hosts may reflect the ancestral phases of the evolution of acanthocephalan endoparasitism (see Taraschewski 2000).

\section{MYZOSTOMIDA}

The position of the Myzostomida, ectocommensals to endoparasites of the Echinodermata (predominantly of Crinoida) is still highly disputable (for reviews see Rouse and Fauchald 1995, 1997a, b, Haszprunar 1996b, Eeckhaut et al. 2000, Zrzavý et al. 2001). There has been a growing consensus that myzostomes are modified polychaete annelids (Rouse and Fauchald 1997a). However, some myzostome students (see Eeckhaut and Jangoux 1991, 1993a, b, Eeckhaut et al. 1995, Eeckhaut 1998) have expressed their reservation concerning the polychaete origin of the Myzostomida (based on muscle histology, spermatophore formation, presence of the adult protonephridia, lack of coelomic organisation, and lack of evident body segmentation). Few explicit cladistic analyses of anatomical, ultrastructural, and developmental characters (Haszprunar 1996b, Zrzavý et al. 1998) suggested myzostomes to be basal protostomes rather than annelids. Mattei and Marchand (1987, 1988) have suggested that Myzostomida and Acanthocephala share similar sperm ultrastructure and spermiogenesis. This aberrant sperm morphology was later found also in monogonont and seisonid rotifers (Melone and Ferraguti 1994, Ahrlichs 1998, Ferraguti and Melone 1999), and the character was used to support the monophyly of Syndermata (see above). The myzostome adult protonephridia exhibit similarities to those of some platyzoans, viz., Gnathostomulida, Micrognathozoa, Gastrotricha, and some "Platyhelminthes" (Pietsch and Westheide 1987, Bartolomaeus and Ax 1992, Kristensen and Funch 2000).

Applying the $18 \mathrm{~S}$ rDNA data to the myzostome problem (Zrzavý et al. 2001) clearly shows that the clade including Syndermata, Cycliophora, and Myzostomida within the Platyzoa is strongly supported by molecular and combined molecular-morphological analyses (Figs. 1 and 4). Also analysis of the 18S rDNA and elongation factor-1 $\alpha$ sequences of several myzostomid species (Eeckhaut et al. 2000, see Littlewood et al. 2001) shows that Myzostomida are platyzoans, more closely related to the Rhabditophora than to the Acanthocephala (note that gastrotrichs, gnathostomulids, catenulids, "rotifers", and cycliophorans have not been analysed by Eeckhaut et al. 2000). However, analysis of the $18 \mathrm{~S}$ rDNA sequences yielded trees "with the Myzostomida within a clade including the Arthropoda and Acanthocephala in addition to the Platyhelminthes" (Eeckhaut et al. 2000, 
p. 1387), and all other analyses include no acanthocephalans because their elongation factor- $1 \alpha$ sequences are not known. Moreover, the comprehensive sampling of metazoan elongation factor- $1 \alpha$ sequences (Littlewood et al. 2001) suggests that elongation factor- $1 \alpha$ alone is a poor indicator of phylogenetic relationships at a metazoan level (the myzostomes group within a "clade" including nematodes, cnidarians, sponges, echinoderms, molluscs, acoels, and few rhabditophoran flatworms; its sister "clade" includes vertebrates, arthropods, annelids, and most rhabditophoran flatworms). The results published by Eeckhaut et al. (2000) and Zrzavý et al. (2001) are, consequently, well compatible and differ predominantly in the taxonomical sampling. No single molecular or combined cladistic analysis places myzostomes close to the annelids, nor within the Lophotrochozoa.

Monophyly of the syndermate-cycliophoranmyzostome clade, the Prosomastigozoa (Zrzavý et al. 2001), is compatible with few morphological data (recently discovered Micrognathozoa should probably be included into the Prosomastigozoa as well). Myzostomes and syndermates share highly derived anteriorly directed sperm flagellum with no accessory centriole (Afzelius 1983, Mattei and Marchand 1987 1988, Melone and Ferraguti 1994, Carcupino and Dezfuli 1995, Ahlrichs 1998, Ferraguti and Melone 1999). Unfortunately, the cycliophoran sperm is insufficiently known (Funch and Kristensen 1997) and only (parthenogenetic?) females of the Micrognathozoa are known (Kristensen and Funch 2000). Within the Prosomastigozoa, monophyly of Cycliophora + Myzostomida is best supported by the 18S rDNA data (Zrzavý et al. 2001).

The characters supporting annelid origin of the myzostomes (Nielsen 1995, Rouse and Fauchald 1995 1997a, b, Rouse 1999, Müller and Westheide 2000) are usually either symplesiomorphic (e.g., spiral cleavage, trochophora-like larva, multiciliary epithelial cells) or convergent (e.g., annelid-like chaetae are present in most annelids, myzostomes, echiurids, and some brachiopods, in the ectoproct gizzard armature, and in the cephalopod Kölliker organs; see Lüter and Bartolomaeus 1997, Lüter 2000). Myzostomes possess metameric paired organs like protonephridia and parapodia (five pairs), but numbers of so-called "lateral organs" (of uncertain homology), of marginal cirri, and of gut diverticles do not accord with the protonephridial and parapodial numbers. The putative myzostome teloblastic growth needs confirmation: the embryonic development of the Myzostomida is virtually unknown, and their parapodia are not formed from anterior to posterior (as are parapodia of annelids and limbs of arthropods), but along an irregular sequence $3 \mathrm{rd} \rightarrow 4$ th $\rightarrow$ 2nd $\rightarrow(5$ th +1 st) (Haszprunar 1996b, and references therein). Myzostomes lack epithelial organisation of the musculature, metanephridia, a circulatory system, a true coelom and the eucoelomic anatomy of the gonads (Haszprunar 1996b). The only myzostomid body system which exhibits obvious segmentation traits is their polychaete-like nervous system indicating that the body of Myzostoma is formed by six segments (Müller and Westheide 2000). Importantly, cladistic analysis of the morphology of polychaete families (Rouse and Fauchald 1997a) placed myzostomes either amongst polychaetes with a hypertrophied eversible axial pharynx (Phyllodocida), or, together with spongeparasitic spintherids, at the base of their annelid tree. This uncertainty is evidently caused by the obscured homology of many myzostome structures: they lack a distinct prostomium, peristomium, antennae, palps, nuchal organs, gills, and jaws, i.e., the key characters for hypothesizing inter-relationships among polychaete clades.

In conclusion, myzostomes are platyzoans that exhibit a complicated mixture of annelid-like (Rouse and Fauchald 1997a, b, Müller and Westheide 2000), basal spiralian (Haszprunar 1996b, Zrzavý et al. 1998), and platyzoan/prosomastigozoan (Mattei and Marchand 1987, 1988, Eeckhaut et al. 2000, Zrzavý et al. 2001) characters, as well as unique features possibly linked with their parasitic lifestyle. These results suggest that major body-plan characters (segmentation, parapodia) might have been independently lost or gained in different animal phyla (see Eeckhaut et al. 2000). The "articulate" body plans have evolved at least three times: in Ecdysozoa (Onychophora + Tardigrada + Arthropoda), in Lophotrochozoa (Annelida incl. Pogonophora and possibly also Echiura), and in Platyzoa (Myzostomida).

The phylogenetic analysis of five myzostome $18 \mathrm{~S}$ rDNA sequences (Eeckhaut et al. 2000) yields the tree as follows: (Cystimyzostoma ("Myzostoma" (Notopharyngoides-Contramyzostoma))), with paraphyletic genus "Myzostoma". This pattern suggests that parasites of the stalked crinoids (Cystimyzostoma from isocrinid Metacrinus) form a sister group of parasites/ commensals of the commatuloid crinoids. The phylogeny of myzostomes seems to reflect the phylogeny of their hosts (Ausich 1998). The association between myzostomes and echinoderms is very old and signs of myzostomes' parasitic activities are found on crinoid skeletons back to the Ordovician (Eeckhaut 1998).

It is possible that also some other worm-like protostomes, such as Lobatocerebrum, Jennaria, and Diurodrilus (see Nielsen 1995, Haszprunar 1996b, Rouse and Fauchald 1995, Zrzavý et al. 1998, Kristensen and Funch 2000, Sørensen et al. 2000), will be shown not to belong into the Annelida and to represent new spiralian clades. The same may apply to some of the commensal/parasitic polychaetes (e.g., Histriobdellidae on crustaceans and Spintheridae on sponges) whose phylogenetic relationships are only superficially known (see Rouse and Fauchald 1997a). 


\section{PENTASTOMIDA AS PARASITIC CRUSTACEA}

The position of the Pentastomida within the Metazoa has provoked many debates up to the present. They were always regarded as closely related to arthropods, onychophorans, and/or tardigrades, possibly as representatives of the "pararthropod" grade, sometimes as secondarily modified arthropods. The spermatological data suggested the close relationships between pentastomids and branchiuran crustaceans (Wingstrand 1972, Storch and Jamieson 1992), a conclusion that has subsequently been supported also by $18 \mathrm{~S}$ rDNA sequences (Abele et al. 1989, 1992, Spears and Abele 1997, Zrzavý et al. 1997). The monophyly of the Branchiura + Pentastomida (=Ichthyostraca; Zrzavý et al. 1997), close to the Ostracoda (Ichthyostraca + Ostracoda = Oligostraca; Zrzavý et al. 1997), has also been supported by combined analysis of arthropods $(18 \mathrm{~S}$ rDNA + 28S rDNA + 5.8S rDNA + 12S rDNA + $16 \mathrm{~S}$ rDNA + ubiquitin + morphology; Zrzavý et al. 1997). A more comprehensive study including 139 arthropod 18S rDNA and 28S rDNA sequences (Giribet and Ribera 2000; see also Giribet et al. 2000) suggests that pentastomids are modified crustaceans, closely related to myodocopid ostracods or, less reliably, to branchiurans. The monophyly of the Ichthyostraca and their relationships to the ostracodes seem to be supported also by ovary morphology and oogenesis (Ikuta and Makioka 1999). Moreover, the Pentastomida are extremely short-bodied and few-segmented, with the unsegmented, "annulated" tail (see Walossek and Müller 1994 and references therein). The body including few segments is also shared with branchiurans and ostracods (Zrzavý et al. 1997).

Walossek and Müller (1994, 1997, 1998) and Walossek et al. (1994) have identified peculiar Cambrian phosphatised fossils (Heymonsicambria, Haffnericambria, Bockelericambria) as the pentastomid juveniles. These animals have prominent heads with two pairs of limbs adapted for attachment, slender trunks of four portions, and even such details as paired forehead structures, pores on the inner edges of the head limbs, and paired papillae at the rear of the trunk correspond to the structures of extant pentastomid larvae. Major differences, such as distinctly divided head limbs, partial occurrence of vestigial trunk limbs, and a different mode of trunk development during growth are explained as representing the plesiomorphic state of characters of Pentastomida (Walossek and Müller 1994, 1997, Al-meida and Christoffersen 1999). The fossils document that the most primitive pentastomids were ectoparasites on early marine chordates (Walossek and Müller 1994), which could be considered a further, however indirect, support for the monophyletic Ichthyostraca. It seems that original ectoparasites of the aquatic vertebrates were forced into their internal tissues during their hosts' invasion of the land.
Walossek and Müller (1994) state that "the morphology of stem- and crown-group pentastomids gives no clues for closer relationship with any of the major (eu)arthropod taxa". Instead, several "preeuarthropod" characters are listed, namely, frontal mouth position, morphology of limbs and nervous system, epimorphic development with pseudo-metamerism of the "caudal end", and the cuticular $\beta$-chitin. Some of these characters evidently occur also within the Arthropoda and Crustacea (epimorphosis in Malacostraca, Tantulocarida, Branchiura, most Hexapoda, some Chilopoda, Euchelicerata), others ( $\beta$-chitin) are not present in any other ecdysozoans and must represent a unique autapomorphy (Schmidt-Rhaesa et al. 1998) if not an error. Nevertheless, although all these characters were included into the morphological dataset by Zrzavý et al. (1997), they are not able to overwhelm the other evidence in either morphological or combined trees (Fig. 5).

Other arguments against the crustacean origin of the Pentastomida are stratigraphic. Both Pentastomida and Maxillopoda (a crustacean group including Branchiura, Copepoda, Mystacocarida, Tantulocarida and thecostracan groups, usually also the Ostracoda, possibly the enigmatic Remipedia as well) are known from the Cambrian, and the "morphological disconnection" between the Cambrian pentastomids and maxillopods is not smaller than between their Recent representatives. From the cladistic point of view, all this merely shows that the maxillopodan and/or ichthyostracan radiations are older than palaeontologists have inferred (Cambrian crustaceans including ostracodes were abundant, Branchiura has no fossil record). Any stratigraphic record of a group of uncertain relationships cannot falsify results of phylogenetic analyses. Comparison of studies concerning morphology (Walossek and Müller 1997, 1998, Wills 1997, 1998, Zrzavý et al. 1997, Schram and Hof 1998, Wills et al. 1998), sperm ultrastructure (Storch and Jamieson 1992), sequences of ribosomal DNA (Spears and Abele 1997, Wheeler 1997, Zrzavý et al. 1997, Giribet and Ribera 2000), and sequences of several protein-coding genes (Regier and Shultz 1997, 1998, Edgecombe et al. 2000, Shultz and Regier 2000) shows that monophyly of the Crustacea is uncertain at best, and that monophyly of the Maxillopoda is quite improbable (Fig. 5). Even if the putative autapomorphies of the Maxillopoda (seven thoracic and four abdominal segments, thoracic limbs used exclusively for locomotion and cephalic limbs for feeding; Walossek and Müller 1998) were accepted as reliable indicators of their close relationships, it is not impossible to derive the pentastomids from the basal maxillopodan morphology. To state that monophyly of the Maxillopoda is "beyond question" (Walossek and Müller 1994, p. 34) and that palaeontology of pentastomids "illustrates the limitations of molecular studies" 
A

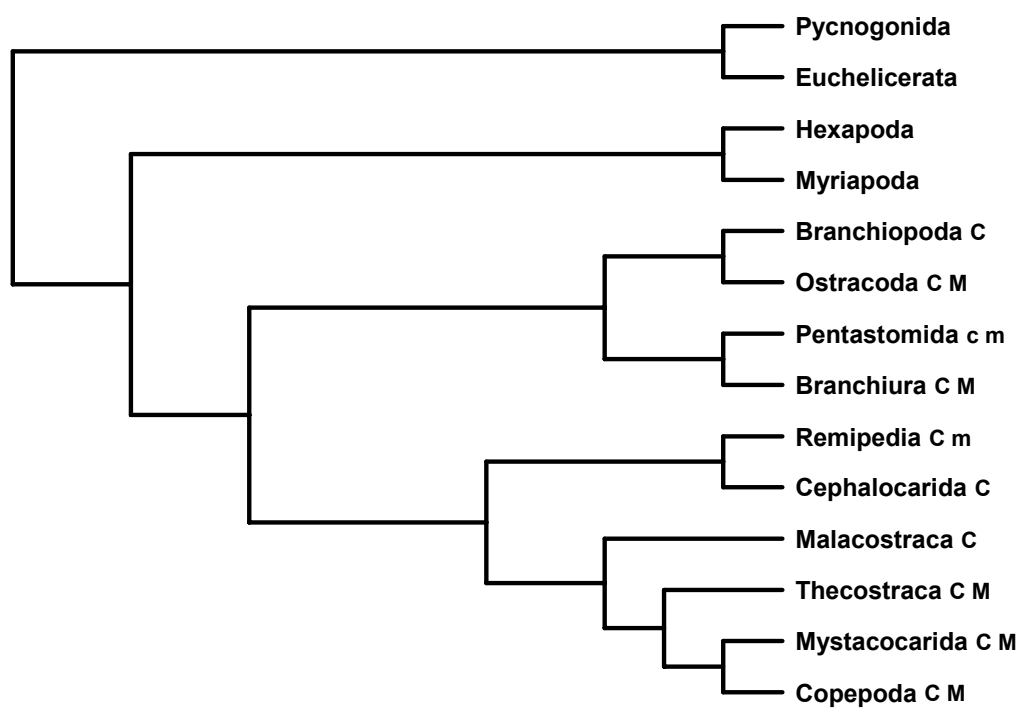

B

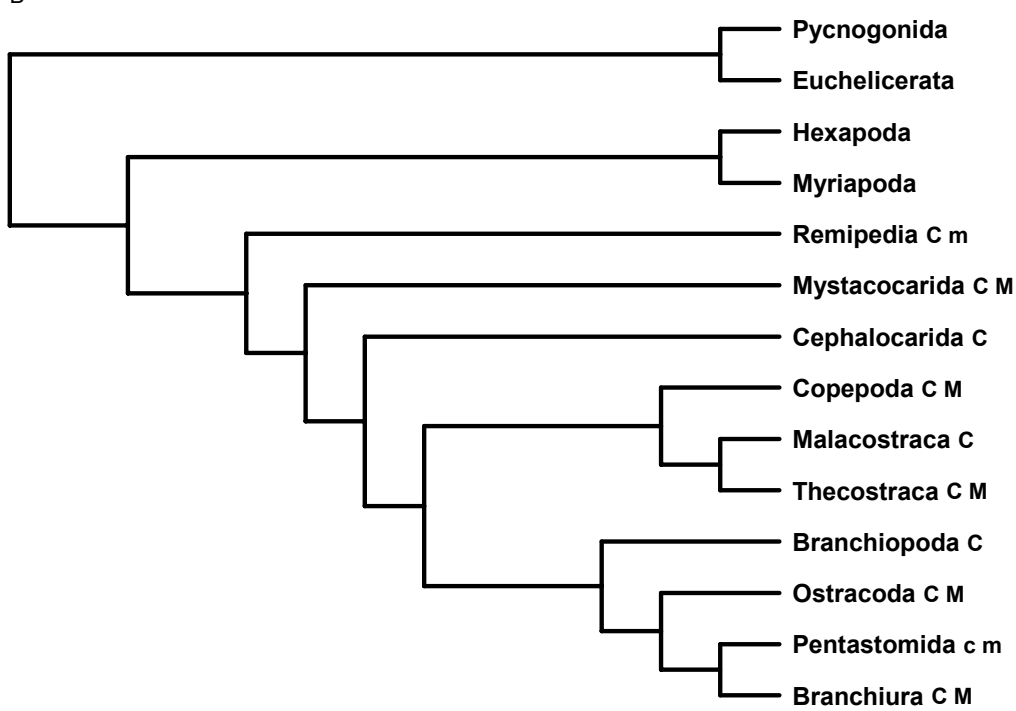

Fig. 5. Possible phylogenetic position of the Pentastomida within the Arthropoda. The tree is combined from Walossek and Müller (1997, 1998, morphological), Wills (1997, 1998, morphological), Spears and Abele (1997, molecular), Wheeler (1997, combined), Zrzavý et al. (1997, combined), Regier and Shultz (1998, molecular), Giribet and Ribera (2000, molecular), and Edgecombe et al. (2000, combined) using the supertree methodology (see Sanderson et al. 1998, Bininda-Emonds et al. 1999): A - morphological source trees weighted twice; $\mathbf{B}$ - molecular source trees weighted twice. $\mathrm{C}-\mathrm{Crustacea}(\mathrm{c}=$ inclusion of the Pentastomida debatable), $\mathrm{M}$ - Maxillopoda $(\mathrm{m}$ = inclusion of the Pentastomida and Remipedia debatable). Note that internal relationships within the Arthropoda are much more disputable than shown here (e.g., position of Pycnogonida, monophyly of Myriapoda + Hexapoda, monophyly of Crustacea, position of most crustacean groups). The data matrix for construction of the arthropod supertrees is published at $<$ http://www.entu.cas.cz/nedved/kzczfylz.htm $>$.

(Walossek and Müller 1997, p. 140) is obviously premature.

The internal relationships among the pentastomid subgroups have received much less attention in the past. Based on 32 morphological characters, Almeida and Christoffersen (1999) provide the following phylogeny:
(Cephalobaenida s. str. (Railietiellida (Reighardiida (Linguatuloidea-Porocephaloidea)))). This is not congruent with the traditional arrangement of the Pentastomida: one of the traditional orders, Cephalobaenida s. lat. is paraphyletic. 


\section{NEMATOMORPHA, BUDDENBROCKIA, AND PARASITIC NEMATODA}

Within the Ecdysozoa, parasitic groups are relatively abundant but they form no phylum-level group, except for the Nematomorpha. These animals are free-living as adults but parasites as juveniles. Two nematomorphan subclades parasitise two taxa of the mandibulate arthropods, Nectonematida in Malacostraca and Gordiida in Hexapoda. Similarly as in the Syndermata, this host-parasite association may indicate close relationships between crustaceans and hexapods (see Regier and Shultz 1997, 1998, Zrzavý et al. 1997, Giribet and Ribera 2000, Shultz and Regier 2000).

Although the Nematomorpha are mostly considered to be closest relatives to the Nematoda (see Nielsen 1995, Nielsen et al. 1996, Schmidt-Rhaesa 1998, Zrzavý et al. 1998, 2001, Giribet et al. 2000), there is a number of similarities with the Scalidophora (=Cephalorhyncha s. str.; = Priapulida + Kinorhyncha + Loricifera; see Fig. 1). Nematomorphans were originally classified as the descendants of ancestral carnivorous scalidophorans that became parasitic and, together with their hosts, invaded freshwater and terrestrial biotopes (Adrianov and Malakhov 1995). Molecular analyses (those including slowly-evolved nematode species) unequivocally support the nematomorphan-nematode sister-group relationships. Autapomorphies of the Nematoida (= Nematozoa s. str.; = Nematomorpha + Nematoda) include ventral and dorsal epidermal cords with mainly unpaired ventral and dorsal nerve cords, cloaca in both sexes, aflagellate spermatozoa, reduction of the circular body musculature, and loss of the protonephridia. The Nematoida are either a sister group of the Panarthropoda (with Scalidophora being the basal ecdysozoans; Zrzavý et al. 1998), or a sister group of the Scalidophora (forming monophyletic Introverta; Nielsen 1995, Schmidt-Rhaesa 1998, Giribet et al. 2000). The presence of eversible introverts with scalides (and/or nematomorphan-like papillae) in various ecdysozoans (Scalidophora, juvenile Nematomorpha, enoplid nematode Kinonchulus; see Nielsen 1995) was used as the most prominent synapomorphy of the Cephalorhyncha s. lat. (incl. nematomorphans; see Adrianov and Malakhov 1995), then dismissed as probably not homologous (Schmidt-Rhaesa 1998), or regarded as an introvertan (or ecdysozoan) symplesiomorphy, second-arily modified/reduced in most nematodes and/or in panarthropods (see e.g. Nielsen 1995, Zrzavý et al. 2001). If the last hypothesis is correct, the nematomorphan parasitic juveniles may represent the ancestral introvertan/ecdysozoan body form, and it is absurd to call this stage a "larva". Instead, the Nematomorpha display a "flounder-like" metamorphic development with an aberrant adult stage. The similarity of adult nematomorphans to the nematodes can be interpreted as a heterochronic shift in the latter group, reducing their possible nematomorphan-like juvenile stages. The problem of biology of the nematode ancestors then becomes quite intriguing.

The molecular tree of the Nematoda based on $18 \mathrm{~S}$ rDNA sequences (Blaxter et al. 1998, 2000, Dorris et al. 1999; see also Schierenberg 2000) shows that Secernentea (=Phasmidia) is a monophyletic group while the "Adenophorea" (="Aphasmidia") is a paraphyletic stemline assemblage. Although the precise origin of the parasitic nematode clades is still uncertain, it is evident that both animal- and plant-parasitic groups have evolved several (or many) times from the freeliving ancestors. The Mermithida, a nematode group most similar to the nematomorphans (arthropodparasitic juveniles, free-living adults), belongs to the basal enoplean ("adenophorean") radiation but their closest relatives are free-living mononchids and freeliving and plant-parasitic dorylaimids. Nothing indicates arthropod-parasitic, nematomorphan-like roots of the Nematoda.

The picture of evolution of the Nematoida is, however, obscured by two problems. First, the position of the arrowworms (Chaetognatha) within Metazoa is quite enigmatic (see Giribet et al. 2000), but some molecular and combined analyses place them within the Ecdysozoa, possibly as a sister group of the Nematoda (Nematozoa s. lat. = Nematoda + Chaetognatha + Nematomorpha; Halanych 1996, Eernisse 1997, Littlewood et al. 1998b, Zrzavý et al. 1998, 2001; Fig. 1 ). This would be further evidence that nematomorphan and mermithid parasitic strategies are not homologous to each other.

Second, one of the most enigmatic animal species, Buddenbrockia plumatellae (see Oda 1972, Nielsen 1995) has been hypothesised to be related either to nematodes or to mesozoans (!), but no ultrastructural, developmental and molecular data are available. Buddenbrockia, a cylindrical organism inhabiting body cavities of the freshwater Ectoprocta around the world, has longitudinal muscular cords, cuticle-like body surface, and no digestive tract; the fragmentary (and obviously dubious) ontogenetic observations suggest that its cell differentiation is not strongly fixed (unlike Nematoda). The only attempt to apply phylogenetic analysis to the available characters (Zrzavý et al. 1998) preliminarily suggests nematoid relationships of Buddenbrockia, with no affinities to the Mesozoa.

\section{EVOLUTION OF PARASITES AND CLADISTIC ANALYSES}

The conclusions of the present paper are certainly subject to revision because sampling must be improved and further sources of the phylogenetic information (e.g., other genes than $18 \mathrm{~S}$ rDNA) should be employed. Despite the recognition of these problems, the 
placement of certain taxa seems to be stable (e.g., monophyly of the Syndermata). At worst, the phylogenetic analyses of the parasitic metazoans clearly show that many marginal, only rarely investigated species might be of a great importance for the evolution of parasites. Polypodium, Notentera, Seison - all these examples should focus the parasitologists' attention to mostly overlooked, and often obscure, sister taxa of the major parasitic clades.

One of the most important conclusions of recent phylogenetic studies for general systematics is a necessity to use exclusively the strictly monophyletic taxa. The discrepancy between phylogenetic position and phenotype of a species is often stronger than anybody has imagined: it seems that some "families" are so different from their relatives that they are convention-ally classified as "phyla". Taxonomical isolation of highly derived aberrant taxa from their "ancestors" then obscures assessment of the diversity of clades and misleads the selection of additional model species. If, for example, myxozoans are truly Polypodium-related cnidarians, their isolation into a separate metazoan subkingdom (Cavalier-Smith 1998a) is reminiscent of Huxley's "kingdom Psychozoa" including exclusively humans (while chimpanzees belonged into the kingdom Animalia). Cavalier-Smith's (1998a) four-subkingdom classification (Radiata, Myxozoa, Bilateria, Mesozoa) suggests that Polypodium is closer to sponges than to Myxozoa; it is hardly possible to imagine any scientific reason why to distort our phylogenetic knowledge so absurdly. Talking about the history of a group, it is easier to do so if the groups are cohesive portions of that history. Moreover, the "classification-is-art" ideology, assuming that delimitation of higher taxa is not a result of phylogenetic analysis but of an a priori assessment of the importance of taxon's structural and biological traits, leads to an obvious unstability and arbitrariness of classification. If the taxa are not clades and a subjective mixture of clades and grades is allowed, there are myriads of possibilities how to translate a single tree into the classification, and a single author can publish "annual or even semi-annual revisions of his 'latest' schemes" (Corliss 1998, p. 426) even if no relevant phylogenetic analyses were performed in the meantime ("... a somewhat simpler system, which I now prefer to that adopted when the present chapter was written ...", Cavalier-Smith 1998b, p. 407, italics added). The non-cladistic classifications are, consequently, of very limited value even for nonscientific, e.g., educational purposes.

It is necessary to ignore formal classifications (if they are not strictly phylogenetic) and to use only trees as bases for future research. The parasitologists, who generally work with derived offshoots of more inclusive clades (like Trematoda and Cestoda vs. "Turbellaria" or Acanthocephala vs. "Rotifera"), should especially be aware of it.

Acknowledgements. This review is based on studies that were supported by grants No. A6022801 (Grant Agency of the Academy of Sciences, Czech Republic) and No. K6005114 (Academy of Sciences, Czech Republic). Tim Littlewood (The Natural History Museum, London), Václav Hypša and Stanislav Mihulka (both Faculty of Biological Sciences, University of South Bohemia, České Budějovice), and an anonymous referee helped to improve the manuscript. The author will be much obliged to anybody who will provide specimens of Buddenbrockia plumatellae for ultrastructural and molecular analyses.

\section{REFERENCES}

ABELE L.G., KIM W., FELGENHAUER B.E. 1989: Molecular evidence for inclusion of the phylum Pentastomida in the Crustacea. Mol. Biol. Evol. 6: 685-691.

ABELE L.G., SPEARS T., KIM W., APPLEGATE M. 1992: Phylogeny of selected maxillopodan and other crustacean taxa based on $18 \mathrm{~S}$ ribosomal nucleotide sequences - a preliminary analysis. Acta Zool. 73: 373-382.

ADOUTTE A., BALAVOINE G., LARTILLOT N., LESPINET O., PRUD'HOMME B., DE ROSA R. 2000: The new animal phylogeny: reliability and implications. Proc. Natl. Acad. Sci. USA 97: 4453-4456.

ADRIANOV A.V., MALAKHOV V.V. 1995: Comparative morphological analysis of the organization of cephalorhynch worms, the phylogeny and the system of the phylum Cephalorhyncha. 5. Phylogeny and system. Zool. Zh. 74: 19-27. (In Russian.)

AFZELIUS B.A. 1983: The spermatozoon of Myzostomum cirriferum (Annelida, Myzostomida). J. Ultrastr. Res. 83: 58-68.
AGUINALDO A.M.A., TURBEVILLE J.M., LINFORD L.S., RIVERA M.C., GAREY J.R., RAFF R.A., LAKE J.A. 1997: Evidence of a clade of nematodes, arthropods, and other moulting animals. Nature 387: 489-493.

AHLRICHS W. 1993: Ultrastructure of the protonephridia of Seison annulatus (Rotifera). Zoomorphology 113: 245251.

AHLRICHS W.H. 1997: Epidermal ultrastructure of Seison nebaliae and Seison annulatus, and a comparison of epidermal structures within the Gnathifera. Zoomorphology 117: 41-48.

AHLRICHS W.H. 1998: Spermatogenesis and ultrastructure of the spermatozoa of Seison nebaliae (Syndermata). Zoomorphology 118: 255-261.

ALBRECHT H., EHLERS U., TARASCHEWSKI H. 1997: Syncytial organization of acanthors of Polymorphus minutus (Palaeacanthocephala), Neoechinorhynchus rutili (Eoacanthocephala), and Moniliformis moniliformis (Archiacanthocephala) (Acanthocephala). Parasitol. Res. 83: 326-338. 
ALESHIN V.V., VLADYCHENSKAYA N.S., KEDROVA O.S., MILYUTINA I.A., PETROV N.B. 1999: Molecular punctuated equilibrium in the evolution of Rhopalura ophiocomae (Mesozoa: Orthonectida) 18S rRNA, hairpin 17. Mol. Biol. 33: 278-287.

ALMEIDA W.D., CHRISTOFFERSEN M.L. 1999: A cladistic approach to relationships in Pentastomida. J. Parasitol. 85: 695-704.

ANDERSON C.L. 1998: Phylogenetic relationships of the Myxozoa. In: G.H. Coombs, K. Vickerman, M.A. Sleigh and A. Warren (Eds.), Evolutionary Relationships among Protozoa. Chapman and Hall, London, pp. 341-350.

ANDERSON C.L., CANNING E.U., OKAMURA B. 1998: A triploblast origin for Myxozoa? Nature 392: 346-347.

ANDERSON C.L., CANNING E.U., OKAMURA B. 1999: Molecular data implicate bryozoans as hosts for PKX (Phylum Myxozoa) and identify a clade of bryozoan parasites within the Myxozoa. Parasitology 119: 555-561.

ANDERSON C.L., CANNING E.U., SCHAFER S.M., YOKOYAMA H., OKAMURA B. 2000: Molecular confirmation of the life cycle of Thelohanellus hovorkai Achmerov, 1960 (Myxozoa: Myxosporea). Bull. Eur. Assoc. Fish Pathol. 20: 111-115.

AUSICH W.I. 1998: Early phylogeny and subclass division of the Crinoidea. J. Paleontol. 72: 499-510.

AX P. 1996: Multicellular Animals: A New Approach to the Phylogenetic Order in Nature, Vol. 1. Springer-Verlag, Berlin, $225 \mathrm{pp}$.

BAGUÑ̇̀ J., CARRANZA S., PAPS J., RUIZ-TRILLO I., RIUTORT M. 2001: Molecular taxonomy and phylogeny of the Tricladida. In: D.T.J. Littlewood and R.A. Bray (Eds.), Interrelationships of the Platyhelminthes. Taylor \& Francis, London, pp. 49-56.

BARTOLOMAEUS T., AX P. 1992: Protonephridia and metanephridia - their relation within the Bilateria. Z. Zool. Syst. Evol. 30: 21-45.

BERNEY C., PAWLOWSKI J., ZANINETTI L. 2000: Elongation factor 1-alpha sequences do not support an early divergence of the Acoela. Mol. Biol. Evol. 17: 10321039.

BININDA-EMONDS O.R.P., GITTLEMAN J.L., PURVIS A. 1999: Building large trees by combining phylogenetic information: a complete phylogeny of the extant Carnivora (Mammalia). Biol. Rev. Camb. Philos. Soc. 74: 143-175.

BLAXTER M.L., DE LEY P., GAREY J.R., LIU L.X., SCHELDEMAN P., VIERSTRAETE A., VANFLETEREN J.R., MACKEY L.Y., DORRIS M., FRISSE L.M., VIDA J.T., THOMAS W.K. 1998: A molecular evolutionary framework for the phylum Nematoda. Nature 392: 71-75

BLAXTER M., DORRIS M., DE LEY P. 2000: Patterns and processes in the evolution of animal parasitic nematodes. Nematology 2: 43-55.

BOEGER W.A., KRITSKY D.C. 2001: Phylogeny of the Monogenoidea: a critical review of hypotheses. In: D.T.J. Littlewood and R.A. Bray (Eds.), Interrelationships of the Platyhelminthes. Taylor \& Francis, London, pp. 92-102.

CAMPOS A., CUMMINGS M.P., REYES J.L., LACLETTE J.P. 1998: Phylogenetic relationships of Platyhelminthes based on 18S ribosomal gene sequences. Mol. Phylogen. Evol. 10: 1-10.

CANNING E.U., CURRY A., FEIST S.W., LONGSHAW M., OKAMURA B. 1999: Tetracapsula bryosalmonae n. sp. for PKX organism, the cause of PKD in salmonid fish. Bull. Eur. Assoc. Fish Pathol. 19: 203-206.

CANNING E.U., CURRY A., FEIST S.W., LONGSHAW M., OKAMURA B. 2000: A new class and order of myxozoans to accommodate parasites of bryozoans with ultrastructural observations on Tetracapsula bryosalmonae (PKX organism). J. Euk. Microbiol. 47: 456468.

CANNING E.U., OKAMURA B., CURRY A. 1996: Development of a myxozoan parasite Tetracapsula bryozoides gen. $\mathrm{n}$. et sp. $\mathrm{n}$. in Cristatella mucedo (Bryozoa: Phylactolaemata). Folia Parasitol. 43: 249-261.

CARCUPINO M., DEZFULI B.S. 1995: Ultrastructural study of mature sperm of Pomphorhynchus laevis Muller (Acanthocephala, Palaeacanthocephala), a fish parasite. Invertebr. Reprod. Dev. 28: 25-32.

CAVALIER-SMITH T. 1983: A 6-kingdom classification and a unified phylogeny. In: W. Schwemmler and H.E.A. Schenk (Eds.), Endocytobiology, Vol. II. De Gruyter, Berlin, pp. 1027-1034.

CAVALIER-SMITH T. 1993: Kingdom Protozoa and its 18 phyla. Microbiol. Rev. 57: 953-994.

CAVALIER-SMITH T. 1997: Amoeboflagellates and mitochondrial cristae in eukaryote evolution: mega-systematics of the new protozoan subkingdoms Eozoa and Neozoa. Arch. Protistenkd. 147: 237-258.

CAVALIER-SMITH T. 1998a: A revised six-kingdom system of life. Biol. Rev. Camb. Philos. Soc. 73: 203-266.

CAVALIER-SMITH T. 1998b: Neomonada and the origin of animals and fungi. In: G.H. Coombs, K. Vickerman, M.A. Sleigh and A. Warren (Eds.), Evolutionary Relationships among Protozoa. Chapman and Hall, London, pp. 375407.

CAVALIER-SMITH T., ALLSOPP M.T.E.P., CHAO E.E., BOURY-ESNAULT N., VACELET J. 1996: Sponge phylogeny, animal monophyly, and the origin of the nervous system: 18S rRNA evidence. Can. J. Zool. 74: 2031-2045.

CLÉMENT P. 1993: The phylogeny of rotifers - molecular, ultrastructural and behavioral data. Hydrobiologia 255: 527-544.

CLÉMENT P., WURDAK E. 1991: Rotifera. In: F.W. Harrison and E.E. Ruppert (Eds.), Microscopic Anatomy of Invertebrates, Vol. 4: Aschelminthes. Wiley-Liss, New York, pp. 219-297.

CORLISS J.O. 1998: Classification of protozoa and protists: the current status. In: G.H. Coombs, K. Vickerman, M.A. Sleigh and A. Warren (Eds.), Evolutionary Relationships among Protozoa. Chapman and Hall, London, pp. 409447.

CZAKER R. 1994: Kantharella antarctica, a new and unusual dicyemid mesozoan from the Antarctic. Zool. Anz. 232: 151-158.

CZAKER R. 2000: Extracellular matrix (ECM) components in a very primitive multicellular animal, the dicyemid meso-zoan Kantharella antarctica. Anat. Rec. 259: 52-59. 
de ROSA R., GRENIER J.K., ANDREEVA T., COOK C.E., ADOUTTE A., AKAM M., CARROLL S.B., BALAVOINE G. 1999: Hox genes in brachiopods and priapulids and protostome evolution. Nature 399: 772-776.

DEHEYN D., WATSON N.A., JANGOUX M. 1998: Symbioses in Amphipholis squamata (Echinodermata, Ophiuroidea, Amphiuridae): geographical variation of infestation and effect of symbionts on the host's light production. Int. J. Parasitol. 28: 1413-1424.

DEWEL R.A. 2000: Colonial origin for Eumetazoa: major morphological transitions and the origin of bilaterian complexity. J. Morphol. 243: 35-74.

DORRIS M., DE LEY P., BLAXTER M.L. 1999: Molecular analysis of nematode diversity and the evolution of parasitism. Parasitol. Today 15: 188-193.

EDGECOMBE G.D., WILSON G.D.F., COLGAN D.J., GRAY M.R., CASSIS G. 2000: Arthropod cladistics: combined analysis of histone $\mathrm{H} 3$ and $\mathrm{U} 2$ snRNA sequences and morphology. Cladistics 16: 155-203.

EECKHAUT I. 1998: Mycomyzostoma calcidicola gen. et sp. nov., the first extant parasitic myzostome infesting crinoid stalks, with a nomenclatural appendix by M.J. Grygier. Species Diversity 3: 89-103.

EECKHAUT I., DOCHY B., JANGOUX M. 1995: Functional morphology of the introvert and digestive system of Myzostoma cirriferum (Myzostomida). Acta Zool. 76: 307-315.

EECKHAUT I., JANGOUX M. 1991: Fine structure of spermatophore and intradermic penetration of sperm cells in Myzostoma cirriferum (Annelida, Myzostomida). Zoomorphology 111: 49-58.

EECKHAUT I., JANGOUX M. 1993a: Integument and epidermal sensory structures of Myzostoma cirriferum (Myzostomida). Zoomorphology 113: 33-45.

EECKHAUT I., JANGOUX M. 1993b: Life cycle and mode of infestation of Myzostoma cirriferum (Annelida), a symbiotic myzostomid of the comatulid crinoid Antedon bifida (Echinodermata). Dis. Aquat. Org. 15: 207-217.

EECKHAUT I., McHUGH D., MARDULYN P., TIEDEMANN P., MONTEYNE D., JANGOUX M., MILINKOVITCH M.C. 2000: Myzostomida: a link between trochozoans and flatworms? Proc. R. Soc. Lond. B 267: 1383-1392.

EERNISSE D.J. 1997: Arthropod and annelid relationships reexamined. In: R.A. Fortey and R.H. Thomas (Eds.), Arthropod Relationships. Chapman and Hall, London, pp. 43-56.

EERNISSE D.J., KLUGE A. 1993: Taxonomic congruence versus total evidence, and amniote phylogeny inferred from fossils, molecules, and morphology. Mol. Biol. Evol. 10: $1170-1195$.

EHLERS U. 1992: Frontal glandular and sensory structures in Nemertoderma (Nemertodermatida) and Paratomella (Acoela) - ultrastructure and phylogenetic implications for the monophyly of the Euplathelminthes (Platyhelminthes). Zoomorphology 112: 227-236.

FERRAGUTI M., MELONE G. 1999: Spermiogenesis in Seison nebaliae (Rotifera, Seisonidea): further evidence of a rotifer-acanthocephalan relationship. Tissue Cell 31: 428-440.
FIELD K.G., OLSEN G.J., LANE D.J., GIOVANNONI S.J., GHISELIN M.T., RAFF E.C., PACE N.R., RAFF R.A. 1988: Molecular phylogeny of the animal kingdom. Science 239: 748-753.

FUNCH P., KRISTENSEN R.M. 1997: Cycliophora. In: F.W. Harrison and R.M. Woollacott (Eds.), Microscopic Anatomy of Invertebrates, Vol. 13: Lophophorates, Entoprocta, and Cycliophora. Wiley-Liss, New York, pp. 409-474.

FURUYA H., TSUNEKI K., KOSHIDA Y. 1996: The cell lineages of two types of embryo and a hermaphroditic gonad in dicyemid mesozoans. Dev. Growth Differ. 38: 453-463.

FURUYA H., TSUNEKI K., KOSHIDA Y. 1997. Fine structure of dicyemid mesozoans, with special reference to cell junctions. J. Morphol. 231: 297-305.

GARCIA-VARELA M., de LEON G.P.P., de la TORRE P., CUMMINGS M.P., SARMA S.S.S., LACLETTE J.P. 2000: Phylogenetic relationships of Acanthocephala based on analysis of $18 \mathrm{~S}$ ribosomal RNA gene sequences. J. Mol. Evol. 50: 532-540.

GAREY J.R., NEAR T.J., NONNEMACHER M.R., NADLER S.A. 1996: Molecular evidence for Acanthocephala as a subtaxon of Rotifera. J. Mol. Evol. 43: $287-$ 292.

GAREY J.R., SCHMIDT-RHAESA A., NEAR T.J., NADLER S.A. 1998: The evolutionary relationships of rotifers and acanthocephalans. Hydrobiologia 387: 83-91.

GATESY J., DeSALLE R., WHEELER W. 1993: Alignmentambiguous nucleotide sites and the exclusion of systematic data. Mol. Phylogen. Evol. 2: 152-157.

GIRIBET G., DISTEL D.L., POLZ M., STERRER W., WHEELER W.C. 2000: Triploblastic relationships with emphasis on the acoelomates and the position of Gnathostomulida, Cycliophora, Plathelminthes, and Chaetognatha: a combined approach of 18S rDNA sequences and morphology. Syst. Biol. 49: 539-562.

GIRIBET G., RIBERA C. 1998: The position of arthropods in the animal kingdom: a search for a reliable outgroup for internal arthropod phylogeny. Mol. Phylogen. Evol. 9: 481-488.

GIRIBET G., RIBERA C. 2000: A review of arthropod phylogeny: new data based on ribosomal DNA sequences and direct character optimization. Cladistics 16: 204-231.

HALANYCH K.M. 1996: Testing hypotheses of chaetognath origins: long branches revealed by $18 \mathrm{~S}$ ribosomal DNA. Syst. Biol. 45: 223-246.

HANELT B., VanSCHYNDEL D., ADEMA C.M., LEWIS L.A., LOKER E.S. 1996: The phylogenetic position of Rhopalura ophiocomae (Orthonectida) based on $18 \mathrm{~S}$ ribosomal DNA sequence analysis. Mol. Biol. Evol. 13: 1187-1191.

HASZPRUNAR G. 1996a: Plathelminthes and Plathelminthomorpha - paraphyletic taxa. J. Zool. Syst. Evol. Res. 34: 41-48.

HASZPRUNAR G. 1996b: The Mollusca: coelomate turbellarians or mesenchymate annelids? In: J.D. Taylor (Ed.), Origin and Evolutionary Radiation of the Mollusca. Oxford Univ. Press, Oxford, pp. 1-28. 
HAUSDORF B. 2000: Early evolution of the Bilateria. Syst. Biol. 49: 130-142.

HENRY J.Q., MARTINDALE M.Q., BOYER B.C. 2000: The unique developmental program of the acoel flatworm, Neochildia fusca. Dev. Biol. 220: 285-295.

HERLYN H. 2001: First description of an apical epidermis cone in Paratenuisentis ambiguus (Acanthocephala: Eoacanthocephala) and its phylogenetic implications. Parasitol. Res. 87: 306-310.

HERVIO D.M.L., KENT M.L., KHATTRA J., SAKANARI J., YOKOYAMA H., DEVLIN R.H. 1997: Taxonomy of Kudoa species (Myxosporea), using a small-subunit ribosomal DNA sequence. Can. J. Zool. 75: 2112-2119.

HORVATH P. 1997: Dicyemid mesozoans. In: S.F. Gilbert and A.M. Raunio (Eds.), Embryology: Constructing the Organism. Sinauer Assoc., Inc. Publ., Sunderland, pp. 3138.

IKUTA K., MAKIOKA T. 1999: Ovarian structure and oogenesis in the myodocopid ostracod Vargula hilgendorfii. J. Crustacean Biol. 19: 730-737.

JANIES D.A., MOOI R.J. 1998: Xyloplax is an asteroid. In: M.D. Candia Carevali and F. Bonasoro (Eds.), Echinoderm Research. A.A. Balkema, Rotterdam, 311-316.

JOFFE B.I., KORNAKOVA E.E. 1998: Notentera ivanovi Joffe et al., 1997: a contribution to the question of phylogenetic relationships between 'turbellarians' and the parasitic Plathelminthes (Neodermata). Hydrobiologia 383: 245-250.

JOFFE B.I., KORNAKOVA E.E. 2001: Flatworm phylogeneticist: between molecular hammer and morphological anvil. In: D.T.J. Littlewood and R.A. Bray (Eds.), Interrelationships of the Platyhelminthes. Taylor \& Francis, London, pp. 279-291.

JONDELIUS U. 1998: Flatworm phylogeny from partial $18 \mathrm{~S}$ rDNA sequences. Hydrobiologia 383: 147-154.

JONDELIUS U., RUÍZ-TRILLO I., BAGUÑÀ J., RIUTORT M. 2000: Nemertodermatida: a basal bilaterian group. Proc. 9th Int. Symp. Biology of the Turbellaria: 4.

JUSTINE J.L., IOMINI C., RAIKOVA O.I., MOLLARET I. 1998: The homology of cortical microtubules in platyhelminth spermatozoa: a comparative immunocytochemical study of acetylated tubulin. Acta Zool. 79: 235241.

KATAYAMA T., NISHIOKA M., YAMAMOTO M. 1996: Phylogenetic relationships among turbellarian orders inferred from 18S rDNA sequences. Zool. Sci. 13: 747756.

KATAYAMA T., WADA H., FURUYA H., SATOH N., YAMAMOTO M. 1995: Phylogenetic position of the dicyemid Mesozoa inferred from 18S rDNA sequences. Biol. Bull. (Woods Hole) 189: 81-90.

KENT M.L., ANDREE K.P., BARTHOLOMEW J.P., ELMATBOULI M., DESSER S.S., DEVLIN R.H., HEDRICK R.P., HOFFMANN R., KHATTRA J.W., HALLETT S.L., LESTER R.J.G., PALENZEULA O., SIDDALL M.E., XIAO C. 2001. Recent advances in our knowledge of the Myxozoa. J. Euk. Microbiol. (in press).

KENT M.L., KHATTRA J., HEDRICK R.P., DEVLIN R.H. 2000: Tetracapsula renicola n. sp (Myxozoa: Saccosporidae); the PKX myxozoan - the cause of proliferative kidney disease of salmonid fishes. J. Parasitol. 86: 103111.

KENT M.L., KHATTRA J., HERVIO D.M.L., DEVLIN R.H. 1998: Ribosomal DNA sequence analysis of isolates of the PKX myxosporean and their relationship to members of the genus Sphaerospora. J. Aquat. Anim. Health 10: 1221.

KOBAYASHI M., FURUYA H., HOLLAND P.W.H. 1999: Dicyemids are higher animals. Nature 401: 762.

KORNAKOVA E.E., JOFFE B.I. 1999: A new variant of the neodermatan-type spermiogenesis in a parasitic 'turbellarian', Notentera ivanovi (Platyhelminthes) and the origin of the Neodermata. Acta Zool. 80: 135-151.

KOZLOFF E.N. 1994: The structure and origin of the plasmodium of Rhopalura ophiocomae (phylum Orthonectida). Acta Zool. 75: 191-199.

KRISTENSEN R.M., FUNCH P. 2000: Micrognathozoa: a new class with complicated jaws like those of Rotifera and Gnathostomulida. J. Morphol. 246: 1-49.

LITTLEWOOD D.T.J., CURINI-GALLETTI M., HERNIOU E.A. 2000: The interrelationships of Proseriata (Platyhelminthes: Seriata) tested with molecules and morphology. Mol. Phylogen. Evol. 16: 449-466.

LITTLEWOOD D.T.J., OLSON P.D. 2001: Small subunit rDNA and the Platyhelminthes: signal, noise, conflict and compromise. In: D.T.J. Littlewood and R.A. Bray (Eds.), Interrelationships of the Platyhelminthes. Taylor \& Francis, London, pp. 262-278.

LITTLEWOOD D.T.J., OLSON P.D., TELFORD M.J., HERNIOU E.A., RIUTORT M. 2001: Elongation factor 1-alpha sequences alone do not assist in resolving the position of the Acoela within the Metazoa. Mol. Biol. Evol. 18: 437-442.

LITTLEWOOD D.T.J., ROHDE K., BRAY R.A., HERNIOU E.A. 1999a: Phylogeny of the Platyhelminthes and the evolution of parasitism. Biol. J. Linn. Soc. 68: 257-287.

LITTLEWOOD D.T.J., ROHDE K., CLOUGH K.A. 1998a: The phylogenetic position of Udonella (Platyhelminthes). Int. J. Parasitol. 28: 1241-1250.

LITTLEWOOD D.T.J., ROHDE K., CLOUGH K.A. 1999b: The interrelationships of all major groups of Platyhelminthes: phylogenetic evidence from morphology and molecules. Biol. J. Linn. Soc. 66: 75-114.

LITTLEWOOD D.T.J., SMITH A.B., CLOUGH K.A., EMSON R.H. 1997: The interrelationships of the echinoderm classes: morphological and molecular evidence. Biol. J. Linn. Soc. 61: 409-438.

LITTLEWOOD D.T.J., TELFORD M.J., CLOUGH K.A., ROHDE K. 1998b: Gnathostomulida - an enigmatic metazoan phylum from both morphological and molecular perspectives. Mol. Phylogen. Evol. 9: 72-79.

LITVAITIS M.K., ROHDE K. 1999: A molecular test of platyhelminth phylogeny - inferences from partial $28 \mathrm{~S}$ rDNA sequences. Invertebr. Biol. 118: 42-56.

LOM J., DYKOVÁ I. 1997: Ultrastructural features of the actinosporean phase of Myxosporea (phylum Myxozoa): a comparative study. Acta Protozool. 36: 83-103.

LORENZEN S. 1985: Phylogenetic aspects of pseudocoelomate evolution. In: S. Conway Morris, J.D. George, R. Gibson and H.M. Platt (Eds.), The Origin and 
Relationships of Lower Invertebrates. Clarendon Press, Oxford, pp. 210-223.

LUNDIN K., HENDELBERG J. 1998: Is the sperm type of the Nemertodermatida close to that of the ancestral Platyhelminthes? Hydrobiologia 383: 197-205.

LÜTER C. 2000: Ultrastructure of larval and adult setae of Brachiopoda. Zool. Anz. 239: 75-90.

LÜTER C., BARTOLOMAEUS T. 1997: The phylogenetic position of Brachiopoda - a comparison of morphological and molecular data. Zool. Scr. 26: 245-253.

MANUEL M., KRUSE M., MULLER W.E.G., Le PARCO Y. 2000: The comparison of beta-thymosin homologues among metazoa supports an arthropod-nematode clade. J. Mol. Evol. 51: 378-381.

MATTEI X., MARCHAND B. 1987: Les spermatozoïdes des Acanthocéphales et des Myzostomides: ressemblance et conséquences phylétiques. C. R. Acad. Sci. Paris 305: 525-529.

MATTEI X., MARCHAND B. 1988: La spermiogenèse de Myzostomum sp. (Procoelomata, Myzostomida). J. Ultrastruct. Mol. Struct. Res. 100: 75-85.

McHUGH D. 1997: Molecular evidence that echiurans and pogonophorans are derived annelids. Proc. Natl. Acad. Sci. U. S. A. 94: 8006-8009.

McHUGH D. 1998: Deciphering metazoan phylogeny: the need for additional molecular data. Am. Zool. 38: 859866.

MELONE G., FERRAGUTI M. 1994: The spermatozoon of Brachionus plicatilis (Rotifera, Monogononta) with some notes on sperm ultrastructure in Rotifera. Acta Zool. 75: 81-88.

MIQUELIS A., MARTIN J.F., CARSON E.W., BRUN G., GILLES A. 2000: Performance of 18S rDNA helix E23 for phylogenetic relationships within and between the Rotifera-Acanthocephala clades. C. R. Acad. Sci. III 323: 925-941.

MOLLARET I., JAMIESON B.G.M., ADLARD R.D., HUGALL A., LECOINTRE G., CHOMBARD C., JUSTINE J.-L. 1997: Phylogenetic analysis of the Monogenea and their relationships with Digenea and Eucestoda inferred from 28S rDNA sequences. Mol. Biochem. Parasitol. 90: 433-438.

MOLLARET I., JAMIESON B.G.M., JUSTINE J.-L. 2000: Phylogeny of the Monopisthocotylea and Polyopisthocotylea (Platyhelminthes) inferred from 28S rDNA sequences. Int. J. Parasitol. 30: 171-185.

MONKS S. 2001: Phylogeny of the Acanthocephala based on morphological characters. Syst. Parasitol. 48: 81-116.

MÜLLER M.C., WESTHEIDE W. 2000: Structure of the nervous system of Myzostoma cirriferum (Annelida) as revealed by immunohistochemistry and cLSM analyses. J. Morphol. 245: 87-98.

NEAR T.J., GAREY J.R., NADLER S.A. 1998: Phylogenetic relationships of the Acanthocephala inferred from $18 \mathrm{~S}$ ribosomal DNA sequences. Mol. Phylogen. Evol. 10: $287-$ 298.

NIELSEN C. 1995: Animal Evolution: Interrelationships of the Living Phyla. Oxford Univ. Press, Oxford, ix +467 pp.
NIELSEN C., SCHARFF N., EIBYE-JACOBSEN D. 1996: Cladistic analyses of the animal kingdom. Biol. J. Linn. Soc. 57: 385-410.

NIXON K.C., CARPENTER J.M. 1996: On simultaneous analysis. Cladistics 12: 221-241.

ODA S. 1972: Some problems on Buddenbrockia. Zool. Mag. (Tokyo) 81: 173-183. (In Japanese.)

PAWLOWSKI J., MONTOYA-BURGOS J.I., FAHRNI J.F., WÜEST J., ZANINETTI L. 1996: Origin of the Mesozoa inferred from 18S ribosomal RNA gene sequences. Mol. Biol. Evol. 13: 1128-1132.

PHILIPPE H., ADOUTTE A. 1998: The molecular phylogeny of Eukaryota: solid facts and uncertainties. In: G.H. Coombs, K. Vickerman, M.A. Sleigh and A. Warren (Eds.), Evolutionary Relationships among Protozoa. Chapman and Hall, London, pp. 25-56.

PIETSCH A., WESTHEIDE W. 1987: Protonephridial organs in Myzostoma cirriferum (Myzostomida). Acta Zool. 68: 195-203.

RAIKOVA E.V. 1990: Fine structure of the nematocysts of Polypodium hydriforme Ussov (Cnidaria). Zool. Scr. 19: $1-11$.

RAIKOVA E.V. 1994: Life cycle, cytology, and morphology of Polypodium hydriforme, a coelenterate parasite of the eggs of acipenseriform fishes. J. Parasitol. 80: 1-22.

RAIKOVA O.I., FLYATCHINSKAYA L.P., JUSTINE J.-L. 1998a: Acoel spermatozoa: ultrastructure and immunocytochemistry of tubulin. Hydrobiologia 383: 207-214.

RAIKOVA O.I., JUSTINE J.-L. 1999: Microtubular system during spermiogenesis and in the spermatozoon of Convoluta saliens (Platyhelminthes, Acoela): tubulin immunocytochemistry and electron microscopy. Mol. Reprod. Dev. 52: 74-85.

RAIKOVA O.I., REUTER M., KOTIKOVA E.A., GUSTAFSSON M.K.S. 1998b: A commisural brain! The pattern of 5-HT immunoreactivity in Acoela (Plathelminthes). Zoomorphology 118: 69-77.

RAIKOVA O.I., REUTER M., JONDELIUS U., GUSTAFSSON M.K.S. 2000: The brain of the Nemertodermatida (Platyhelminthes) as revealed by anti-5HT and anti-FMRFamide immunostainings. Tissue Cell 32: 358365.

REGIER J.C., SHULTZ J.W. 1997: Molecular phylogeny of the major arthropod groups indicates polyphyly of crustaceans and a new hypothesis for the origin of hexapods. Mol. Biol. Evol. 14: 902-913.

REGIER J.C., SHULTZ J.W. 1998: Molecular phylogeny of arthropods and the significance of the Cambrian "explosion" for molecular systematics. Am. Zool. 38: 918928.

REUTER M., RAIKOVA O.I., GUSTAFSSON M.K.S. 1998: An endocrine brain? The pattern of FMRF-amide immunoreactivity in Acoela (Platyhelminthes). Tissue Cell 30: 57-63.

RICCI C. 1998: Are lemnisci and proboscis present in the Bdelloidea? Hydrobiologia 387: 93-96.

RICCI C., MELONE G., SOTGIA C. 1993: Old and new data on Seisonidea (Rotifera). Hydrobiologia 255/256: 495511. 
RIEGER R.M., TYLER S. 1995: Sister-group relationship of Gnathostomulida and Rotifera-Acanthocephala. Invertebr. Biol. 114: 186-188.

ROHDE K. 1996: Robust phylogenies and adaptive radiations: a critical examination of methods used to identify key innovations. Am. Nat. 148: 481-500.

ROHDE K. 1997: The origins of parasitism in the Platyhelminthes: a summary interpreted on the basis of recent literature. Int. J. Parasitol. 27: 739-746.

ROKAS A., HOLLAND P.W.H. 2000: Rare genomic changes as a tool for phylogenetics. Trends Ecol. Evol. 15: 454459.

ROUSE G.W. 1999: Trochophore concepts: ciliary bands and the evolution of larvae in spiralian Metazoa. Biol. J. Linn. Soc. 66: 411-464.

ROUSE G.W., FAUCHALD K. 1995: The articulation of annelids. Zool. Scr. 24: 269-301.

ROUSE G.W. FAUCHALD K. 1997a: Cladistics and polychaetes. Zool. Scr. 26: 139-204.

ROUSE G.W., FAUCHALD K. 1997b: Polychaete systematics: past and present. Zool. Scr. 26: 71-138.

RUÍZ-TRILLO I., RIUTORT M., LITTLEWOOD D.T.J., HERNIOU E.A., BAGUÑ̇̀ J. 1999: Acoel flatworms: earliest extant bilaterian metazoans, not members of Platyhelminthes. Science 283: 1919-1923.

SAITO M., KOJIMA S., ENDO K. 2000: Mitochondrial COI sequences of brachiopods: genetic code shared with protostomes and limits of utility for phylogenetic reconstruction. Mol. Phylogen. Evol. 15: 331-344.

SANDERSON M.J., PURVIS A., HENZE C. 1998: Phylogenetic supertrees: assembling the trees of life. Trends Ecol. Evol. 13: 105-109.

SAULNIER D., PHILIPPE H., de KINKELIN P. 1999: Molecular evidence that the proliferative kidney disease organism unknown (PKX) is a myxosporean. Dis. Aquat. Org. 36: 209-212.

SCHIERENBERG E. 2000: New approaches to a better understanding of nematode phylogeny: molecular and developmental studies. J. Zool. Syst. Evol. Res. 38: 129132.

SCHLEGEL M., LOM J., STECHMANN A., BERNHARD D., LEIPE D., DYKOVÁ I., SOGIN M.L. 1996: Phylogenetic analysis of complete small subunit ribosomal RNA coding region of Myxidium lieberkuehni: evidence that Myxozoa are Metazoa and related to the Bilateria. Arch. Protistenkd. 147: 1-9.

SCHMIDT-RHAESA A. 1998: Phylogenetic relationships of the Nematomorpha - a discussion of current hypotheses. Zool. Anz. 236: 203-216.

SCHMIDT-RHAESA A., BARTOLOMAEUS T., LEMBURG C., EHLERS U., GAREY J.R. 1998: The position of the Arthropoda in the phylogenetic system. J. Morphol. 238: 263-285.

SCHRAM F.A, HOF C.H.J. 1998: Fossils and interrelationships of major crustacean groups. In: G.D. Edgecombe (Ed.), Arthropod Fossils and Phylogeny. Columbia Univ. Press, New York, pp. 233-302.

SCHUCHERT P. 1993: Phylogenetic analysis of the Cnidaria. Z. Zool. Syst. Evolutionsforsch. 31: 161-173.
SERAVIN L.N., RAIKOVA E.B. 1994: The cells of Polypodium hydriforme Ussov (Cnidaria) display mitochondria with tubular cristae. Dokl. Akad. Nauk 336: 418420.

SHOSTAK S., KOLLURI V. 1995: Symbiogenetic origins of cnidarian cnidocysts. Symbiosis 19: 1-29.

SHULTZ J.W., REGIER J.C. 2000: Phylogenetic analysis of arthropods using two nuclear protein-encoding genes supports a crustacean + hexapod clade. Proc. R. Soc. Lond. B 267: 1011-1019.

SIDDALL M.E., MARTIN D.S., BRIDGE D., DESSER S.S., CONE D.K. 1995: The demise of a phylum of protists: phylogeny of Myxozoa and other parasitic cnidaria. J. Parasitol. 81: 961-967.

SIDDALL M.E., WHITING M.F. 1999: Long-branch abstractions. Cladistics 15: 9-24.

SIMMONS M.P. 2000: A fundamental problem with aminoacid sequence characters for phylogenetic analyses. Cladistics 16: 274-282.

SLYUSAREV G.S. 1994: Fine structure of the female Intoshia variabili (Alexandrov and Sljusarev) (Mesozoa, Orthonectida). Acta Zool. 75: 311-321.

SLYUSAREV G.S 2000: Fine structure and development of the cuticle of Intoshia variabili (Orthonectida). Acta Zool. 81: $1-8$

SLYUSAREV G.S., MILLER D.M. 1998: Fine structure of the mature plasmodium of Intoshia variabili (phylum Orthonecta), a parasite of the platyhelminth Macrorhynchus crocea. Acta Zool. 79: 319-327.

SMOTHERS J.F., VONDOHLEN C.D., SMITH L.H., SPALL R.D. 1994: Molecular evidence that the myxozoan protists are metazoans. Science 265: 1719-1721.

SØRENSEN M.V. 2000: An SEM study of the jaws of Haplognathia rosea and Rastrognathia macrostoma (Gnathostomulida), with a preliminary comparison with the rotiferan trophi. Acta Zool. 81: 9-16.

SØRENSEN M.V., FUNCH P., WILLERSLEV E., HANSEN A.J., OLESEN J. 2000: On the phylogeny of the Metazoa in light of Cycliophora and Micrognathozoa. Zool. Anz 239: 297-318.

SPEARS T., ABELE L.G. 1997: Crustacean phylogeny inferred from 18S rDNA. In: R.A. Fortey and R.H. Thomas (Eds.), Arthropod Relationships. Chapman and Hall, London, pp. 169-187.

STECHMANN A., SCHLEGEL M. 1999: Analysis of the complete mitochondrial DNA sequence of the brachiopod Terebratulina retusa places Brachiopoda within the protostomes. Proc. R. Soc. Lond. B 266: 2043- 2052.

STILLER J.W., HALL B.D. 1999: Long-branch attraction and the rDNA model of early eukaryotic evolution. Mol. Biol. Evol. 16: 1270-1279.

STORCH V., JAMIESON B.G.M. 1992: Further spermatological evidence for including the Pentastomida (tongue worms) in the Crustacea. Int. J. Parasitol. 22: 95-108.

TARASCHEWSKI H. 2000: Host-parasite interactions in Acanthocephala: a morphological approach. Adv. Parasitol. 46: 1-179.

TELFORD M.J. 2000: Turning Hox "signatures" into synapomorphies. Evol. Dev. 2: 360-364. 
TELFORD M.J., HERNIOU E.A., RUSSELL R.B., LITTLEWOOD D.T.J. 2000: Changes in mitochondrial genetic codes as phylogenetic characters: two examples from the flatworms. Proc. Natl. Acad. Sci. U.S.A. 97: 1135911364.

WALLACE R.L., RICCI C., MELONE G. 1996: A cladistic analysis of pseudocoelomate (aschelminth) morphology. Invertebr. Biol. 115: 104-112.

WALOSSEK D., MÜLLER K.J. 1994: Pentastomid parasites from the Lower Paleozoic of Sweden. Trans. R. Soc. Edinb. Earth Sci. 85: 1-37.

WALOSSEK D., MÜLLER K.J. 1997: Cambrian 'Orsten'type arthropods and the phylogeny of Crustacea. In: R.A. Fortey and R.H. Thomas (Eds.), Arthropod Relationships. Chapman and Hall, London, pp. 139-153.

WALOSSEK D., MÜLLER K.J. 1998: Early arthropod phylogeny in light of the Cambrian "Orsten" fossils. In: G.D. Edgecombe (Ed.), Arthropod Fossils and Phylogeny. Columbia Univ. Press, New York, pp. 185-231.

WALOSSEK D., REPETSKI J.E., MULLER K.J. 1994: An exceptionally preserved parasitic arthropod, Heymonsicambria taylori n. sp. (Arthropoda incertae sedis, Pentastomida), from Cambrian-Ordovician boundary beds of Newfoundland, Canada. Can. J. Earth Sci. 31: 16641671.

WATANABE K.I., BESSHO Y., KAWASAKI M., HORI H. 1999: Mitochondrial genes are found on minicircle DNA molecules in the mesozoan animal Dicyema. J. Mol. Biol. 286: 645-650.

WATSON N.A. 1997: Proximo-distal fusion of flagella during spermiogenesis in the "turbellarian" platyhelminth Urastoma cyprinae, and phylogenetic implications. Invertebr. Reprod. Dev. 32: 107-117.

WELCH D.B.M. 2000: Evidence from a protein-coding gene that acanthocephalans are rotifers. Invertebr. Biol. 119: $17-26$.

WHEELER W.C. 1994: Sequence alignment, parameter sensitivity and the phylogenetic analysis of molecular data. Syst. Biol. 44: 321-331.

WHEELER W.C. 1997: Sampling, groundplans, total evidence and the systematics of arthropods. In: R.A. Fortey and R.H. Thomas (Eds.), Arthropod Relationships. Chapman and Hall, London, pp. 87-96.

WHEELER W.C., CARTWRIGHT P., HAYASHI C.Y. 1993: Arthropod phylogeny: a combined approach. Cladistics 9: 1-39.

WHEELER W.C., GATESY J., DeSALLE R. 1995: Elision: a method for accommodating multiple molecular sequence alignments with alignment-ambiguous sites. Mol. Phylogen. Evol. 4: 1-9.
WHITING M.F., CARPENTER J.C., WHEELER Q.D., WHEELER W.C. 1997: The Strepsiptera problem: phylogeny of the holometabolous insect orders inferred from $18 \mathrm{~S}$ and $28 \mathrm{~S}$ ribosomal DNA sequences and morphology. Syst. Biol. 46: 1-68.

WILLS M.A. 1997: A phylogeny of recent and fossil Crustacea derived from morphological characters. In: R.A. Fortey and R.H. Thomas (Eds.), Arthropod Relationships. Chapman and Hall, London, pp. 189-209.

WILLS M.A. 1998: Crustacean disparity through the Phanerozoic: comparing morphological and stratigraphic data. Biol. J. Linn. Soc. 65: 455-500.

WILLS M.A., BRIGGS D.E.G., FORTEY R.A., WILKINSON M., SNEATH P.H.A. 1998: An arthropod phylogeny based on fossil and recent taxa. In: G.D. Edgecombe (Ed.), Arthropod Fossils and Phylogeny. Columbia Univ. Press, New York, pp. 33-105.

WINGSTRAND K.G. 1972: Comparative spermatology of a pentastomid Raillietiella hemidactyli and a branchiuran crustacean Argulus foliaceus with a discussion of pentastomid relationships. Biol. Skr. K. Dan. Vidensk. Selsk. 19: 1-72.

WINNEPENNINCKX B., BACKELJAU T., KRISTENSEN R. 1998a: Relations of the new phylum Cycliophora. Nature 393: 636-638.

WINNEPENNINCKX B.M.H., VAN de PEER Y., BACKELJAU T. 1998b: Metazoan relationships on the basis of 18S rRNA sequences: a few years later... Am. Zool. 38: 888-906.

XIAO C.X., DESSER S.S. 2000: Cladistic analysis of myxozoan species with known alternating life-cycles. Syst. Parasitol. 46: 81-91.

YEATES D.K. 1995: Groundplans and exemplars: paths to the tree of life. Cladistics 11: 343-357.

ZAMPARO D., BROOKS D.R., HOBERG E.P., McLENNAN D.A. 2001: Phylogenetic analysis of the Rhabdocoela (Platyhelminthes) with emphasis on the Neodermata and relatives. Zool Scr. 30: 59-77.

ZRZAVÝ J., HYPŠA V., TIETZ D.F. 2001: Myzostomida are not annelids: molecular support for a clade of animals with anterior sperm flagella. Cladistics 17 (in press).

ZRZAVÝ J., HYPŠA V., VLÁŠKOVÁ M. 1997: Arthropod phylogeny: taxonomic congruence, total evidence, and conditional combination approaches to morphological and molecular data sets. In: R.A. Fortey and R.H. Thomas (Eds.), Arthropod Relationships. Chapman and Hall, London, pp. 97-107.

ZRZAVÝ J., MIHULKA S., KEPKA P., BEZDĚK A., TIETZ D. 1998: Phylogeny of the Metazoa based on morphological and $18 \mathrm{~S}$ ribosomal DNA evidence. Cladistics 14: 249-285. 